DOI: 10.14394/edufil.2021.0022

ORCID: 0000-0002-0342-4533

\title{
Transgresja w mistyce oblubieńczej Bernarda z Clairvaux
}

\author{
Rafał Tichy \\ (Uniwersytet Warszawski, Wydział Filozofii)
}

\section{Wprowadzenie}

Mistykę Bernarda z Clairvaux zazwyczaj charakteryzuje się jako mistykę miłosną, czy też mistykę oblubieńczą, gdyż to właśnie na temacie miłości oblubieńczej łączącej człowieka i Boga jest skoncentrowana. Choć wiele już o tym miłosnym i oblubieńczym wymiarze doktryny mistycznej Bernarda napisano ${ }^{1}$, to wydaje się, że nie zwrócono dotąd wystarczającej uwagi na jedną z najważniejszych jej cech - jej zuchwałość i w konsekwencji transgresyjność. Tymczasem jest to według Bernarda cecha decydująca o tym, że miłość oblubieńcza może osiągnąć swój cel i nie pozostaje „niczym miedź brzęcząca”. Jako taka zaś jest istotnym punktem odniesienia w jego antropologii i teologii. Wydobycie jej jest więc ważne dla poznania nowych znaczeń, które w swym bogactwie wciąż nam ofiarowu-

Temat miłości jest jednym z najczęściej przewijających się w jego rozważaniach teologicznych i duchowych. Poświęca mu swe pierwsze dzieło List o miłości, którego treść rozwija w późniejszym traktacie $O$ miłowaniu Boga. I wciąż, właściwie we wszystkich traktatach do tego tematu powraca, wyznaczając miłości centralne miejsce w relacji człowieka do Boga oraz podkreślając, że stanowi istotę przesłania ewangelicznego. Por. E. Gilson, La théologie mystique de saint Bernard, Paris 1934, s. 78nn; A.C. Halflants, La doctrine spirituelle de S. Bernard, „Collectanea Cisterciensia” 1976, nr 38, cz. II, s. 40nn; J. Leclercq, La spiritualité du moyen age. De saint Grégoire à saint Bernard, w: Histoire de la spiritualité chrétienne, t. 2, Paris 1961, s. 244-245, s. 244-245; P.P. Delfgaauw, La nature et les degrés de l'amour selon saint Bernardi, w: Saint Bernard théologien. Actes du congrès de Dijon. 15-19 septembre 1953, „Analecta Sacri Ordinis Cisterciensis” 1953, nr 9, Romae 1953, s. 234-252. 
je. Jest też niezwykle ciekawe dla badacza myśli opata z Clairvaux, gdyż ukazuje tego bez wątpienia gorliwego obrońcę ortodoksji jako gotowego w imię mistycznej prawdy o Bogu i człowieku wykraczać poza normy metafizyczne i teologiczne swych czasów i balansować niebezpiecznie na granicy heterodoksji.

\section{Stopnie doskonalenia i doświadczenia}

Bernard odnajduje objawioną prawdę na temat miłości oblubieńczej w biblijnej Pieśni nad pieśniami. Swoje doświadczenia mistycznego podążania jej śladem i swoją doktrynę mistyczną wyjaśniającą jej meandry najpełniej przedstawia więc komentując tą księgę w Kazaniach do Pieśni nad pieśniami².

Analizę zaczyna od usytuowania doświadczenia miłosnego, w które wprowadza Pieśń nad pieśniami, na mapie rozwoju duchowego człowieka. Księga ta mówi według niego o takim etapie wspomnianego rozwoju, na który wejść można jedynie po przejściu dwu wcześniejszych stopni doskonałości duchowej. Bernard charakteryzuje je, odwołując się do zaczerpniętego od Orygenesa i ugruntowanego mocno w tradycji monastycznej podziału na trzy stopnie doskonalenia, które swój duchowy i symboliczny wyraz znalazły w trzech księgach mądrościowych napisanych przez Salomona: Księdze Przysłów, Księdze Eklezjastesa i właśnie Pieśni nad Pieśniami. Opisana w tych trzech księgach mądrość jest zbieżna wedle Orygenesa z trzema działami filozofii: etyka, fizyką i enoptyką rozumianymi jednak nie jako abstrakcyjne dziedziny wiedzy, ale tak, jak rozumiano je w czasach Ojców - jako trzy fundamentalne dziedziny poznania ściśle związane z postępem duchowym ${ }^{3}$. Zgodnie zatem $\mathrm{z}$ tym podziałem Bernard opisuje drogę, którą,

\footnotetext{
Kontynuuje i wieńczy w ten sposób długą patrystyczną i średniowieczną tradycję jej alegorycznych komentarzy. Jego wyrażona w Kazaniach do Pieśni mistyczna analiza tej księgi jest do dziś uznawana za najwspanialszy pod względem teologicznym i pisarskim jej komentarz. Zob. E. Ann Matter, The Voice of My Beloved. The Song of Songs in Western Medieval Christianity, University of Pennsylvania 1992, s. 20-48, 123-150; D. Robertson, Lectio Divina. The Medieval Experience of Reading, Cistercian Publications 2011. Por. też J. M. Déchanet, Amor ipse intellectus est, „Revue du moyen âge latin” 1945, nr 1, s. 349-374. Por. też J. Leclercq, S. Bernard et la théologie monastique du XIIe siècle, w: Saint Bernard théologien, s. 13-15.

3 Orygenes, Komentarz do Pieśni nad pieśniami, Prol. 4, tłum. S. Kalinkowski, Kraków 1994, s. 21-25. Por. P. Hadot, Teologia, egzegeza, objawienie i Pismo w filozofii greckiej, w: Platon, Eutyfron, Warszawa 2015, s. 289-292.
} 
jak ma nadzieję jego cysterscy bracia i uczniowie już przeszli, i która uzdalnia ich do duchowej lektury Pieśni nad pieśniami:

Jeśli się nie mylę, za łaską Boga, zrozumieliście całkiem dobrze, z Księgi Eklezjastesa, w jaki sposób odróżniać i odrzucać fałszywe obietnice tego świata. A następnie Księga Przysłów. Czy wasze życie i wasz sposób postępowania został dostatecznie poprawiony i oświecony, przez doktrynę, którą ona wpaja? [...] Jedna z nich wykorzenia zgubne nawyki umysłu i ciała motyką samo opanowania, samokontroli. Druga, posługując się oświeconym rozumowaniem, prędko postrzega zgubne zabarwienie we wszystkim, co świat uważa za chwalebne, rozróżniając prawdziwie, pomiędzy tym, a głębszą prawdą"4.

Otwarcie się na to o czym mówi Pieśń nad Pieśniami wymaga więc najpierw zgodnego z etyczną mądrością Księgi Przysłów oderwania się poprzez ćwiczenia ascetyczne od zgubnych nawyków ciała, każących nam szukać szczęścia w zaspokojeniu swych pożądań, a następnie zgodnego z fizykalną mądrością Księgi Eklezjastesa, a zyskanego dzięki rozumnym rozważaniom oświecenia, które pozwoli nam zdać sobie sprawę z marności spraw doczesnych. Dzięki temu człowiek zyskuje wolności ducha i oczyszczenie umysłu pozwalające mu „przejść do tego świętego i kontemplacyjnego rozważania”, które najwyraźniej stanowi szczyt duchowego doskonalenia na drodze mądrości i „które jako owoc poprzednich dwóch, może zostać przekazane jedynie dobrze przygotowanym uszom i umysłom"s.

Zanim jednak powie nam, czego dotyczy najwyższa, kontemplacyjna mądrość Pieśni nad Pieśniami, Bernard zmienia perspektywę, z jakiej opisuje drogę doskonalenia. Orygenesowy podział stopni duchowego wznoszenia się kładł nacisk przede wszystkim na jego negatywny wymiar, na oderwanie. Bernard, chcąc lepiej ukazać jej wymiar pozytywny i określić, czym duch w swej wolności się napełnia, dodaje do tego podziału opis duchowego wznoszenia bazujący na specyficznej hierarchii, w jaką układają się biblijne pieśni. Biblia bowiem zawiera bardzo wiele różnorodnych pieśni, które są zawsze świadectwem i wyrazem konkretnego doświadczenia spotkania z Bogiem. Gdy Izrael przechodzi Morze czerwone, gdy Debora, Judyta czy Dawid, opierając się na Bogu, pokonują

4 Bernardus Claraevallensis, Sermones super Cantica Canticorum 1, 2-3, w: Sancti Bernardi Opera, Editiones Cistercienses, ed. J. Leclercq, C.H. Talbot, H.M. Rochais, Romae 1957-1958, t. 1, s. 3-4.

5 Tamże. 
swoich wrogów czy wydobywają się z grzechu, dają temu świadectwo właśnie w kierowanych ku Niemu pieśniach. „Były to pieśni na cześć odniesionego zwycięstwa, na cześć uniknięcia niebezpieczeństwa, albo zdobycia dobra od dawna pożądanego"6. Podobnie mnisi, w zależności od tego, czego doświadczali na drodze duchowej prowadzącej ich poprzez oderwanie i oczyszczenia do Boga, wyrażali to na modlitwie, czy po prostu w głębi swego serca w coraz to innej pieśni kierowanej do Boga „za wszystkie cuda, których dokonał”. Ponieważ zaś język biblijny „przeżuwany” dzień i noc przez mnichów pomagał im w wyrażaniu swoich przeżyć duchowych, nic dziwnego że to właśnie pieśni biblijne towarzyszyły im na tej drodze w sposób szczególny. Dlatego właśnie można je śmiało nazwać „pieśniami stopni”. Każdy, niezależnie od tego, na jakim stopniu rozwoju się znajduje, może zgodnie $z$ wstępującym ruchem swego serca wybrać jedną z tych pieśni, aby oddać chwałę Temu, który daje moc postępowania naprzód"7. Postępowania, które zasadza się na nabieraniu, w miarę odrywania się od świata cielesnych pożądań, coraz większej, opartej na doświadczeniu duchowym zażyłości ze światem duchowym i samym Bogiem.

Skoro to właśnie wyrażają i do tego przygotowują biblijne pieśni stopni, to jakie miejsce zajmuje wśród nich Pieśń nad Pieśniami? Klarowną podpowiedź stanowi już sama jej nazwa. Jest ona „pieśnią nad pieśniami”, gdyż góruje nad pozostałymi pieśniami stopni i stanowi ich zwieńczenie. Wyraża najwyższe dostępne człowiekowi duchowe doświadczenie, do którego wszystkie poprzednie pieśni konsekwentnie prowadzą i przygotowują:

Oto jednak ta inna pieśń, która przez swoją wyjątkową godność i słodycz przewyższa te wszystkie, które wymieniłem i wszystkie inne, które mogłyby być. Dlatego, ze wszech miar, potwierdzam, że jest ona pieśnią nad pieśniami. Jest ona, znajduje się w tym punkcie, gdzie osiągają kulminację wszystkie inne pieśni. Tylko dotknięcie Ducha może natchnąć taką pieśń i tylko osobiste doświadczenie może odsłonić jej znaczenie. Niech ci, którzy są zaznajomieni $\mathrm{z}$ tajemnicą, delektują się nią, niech wszyscy inni płoną raczej pragnieniem osiągnięcia tego doświadczenia, niż tego aby po prostu się o nim dowiedzieć. Nie jest to bowiem melodia, która rozbrzmiewa na zewnątrz, ale muzyka samego serca. Nie jest to trel warg, ale wewnętrzne pulsowanie rozkoszy, harmonia nie głosów, ale woli. Jest to melodia, której nie usłyszycie na ulicach.

Cant. 1, 7, t. 1, s. 5 .

Tamże, 1, 10, t. 1, s. 7 . 
Nuty te nie dźwięczą tam, gdzie zbierają się tłumy. Tylko śpiewający je słyszy i ten, któremu on śpiewa. Miłujący i umiłowany. Jest to przede wszystkim pieśń ślubna, pieśń zaślubin, mówiąca o czystych duszach w miłosnym uścisku, o słodkim zjednoczeniu, albo zgodzie ich woli, o wzajemnej wymianie serdecznych uczuć ${ }^{8}$.

Najgłębszy rodzaj zażyłości z Bogiem dokonuje się zatem w doświadczeniu takiej miłości, która najlepiej daje się opisać poprzez zastosowanie terminologii oblubieńczej, ślubnej, tak jak to czyni Pieśń nad Pieśniami. To miłość „brzemienna rozkoszą", która prowadzi łączące się w niej osoby do relacji najbardziej intymniej - do „słodkiego zjednoczenia” podobnego temu, które pozostaje przywilejem małżonków. Wejście w obszar tego doświadczenia, określanego współcześnie mianem mistycznego, a przynajmniej ukierunkowanie na nie, jest właściwym celem i najgłębszym sensem wznoszenia się po stopniach duchowego doskonalenia:

Nowicjusze, ludzie niedojrzali, ci, którzy dopiero co nawrócili się ze światowego życia, zwykle nie słyszą tej pieśni i jej nie śpiewają. Tylko umysł zdyscyplinowany dzięki wytrwałym studiom, tylko ten człowiek, którego wysiłki przyniosły owoc z natchnienia Bożego, człowiek, którego lata, jakby to powiedzieć, czynią go dojrzałym do małżeństwa, lata mierzone nie czasem ale zasługami, tylko on jest prawdziwie przygotowany na małżeńskie zjednoczenie z boskim małżonkiem, zjednoczenie, które opiszemy pełniej we właściwym czasie?

\section{Stopnie miłości}

Aby dokładniej scharakteryzować cechy mistycznej miłości, Bernard przedstawia nam w dalszych kazaniach do Pieśni nad Pieśniami różne typy miłości, budując zarazem hierarchię ich doskonałości. Hierarchia ta mówi o jeszcze jednym wymiarze wznoszenia duchowego. Człowiek nie łączy się bowiem z Bogiem miłością dopiero wtedy, gdy zacznie prowadzić życie mistyczne. Na kolejnych stopniach duchowego oczyszczenia i oświecenia dane jest nam przeżywać kolejne stany miłosne, które - podobnie jak to dzieje się w przypadku uczuć wiążących

Tamże, 1, 11, t. 1, s. 7-8.

Tamże, 1, 12, t. 1, s. 8 . 
nas z innymi ludźmi - stopniowo dojrzewają i zmieniają charakter, antycypując ten najwyższy, opisany przez Salomona. Bernard poświęca im wiele uwagi, gdyż ukazanie czym niższe oblicza miłości różnią się od miłości oblubieńczej, a w czym są jej pokrewne, ułatwia wydobycie jej oryginalności i specyfiki.

Warto jednak najpierw przypomnieć klasyfikację typów miłości przeprowadzoną przez Bernarda w jego wcześniejszym dziele, czyli w traktacie O miłowaniu Boga. Podział zastosowany w analizie Pieśni jest tej klasyfikacji rozwinięciem.

Bernard wyróżnia cztery stopnie miłości, będące zarazem czterema etapami rozwoju duchowego człowieka. Istotę tego rozwoju stanowi według Bernarda doskonalenie się w miłości. Pierwszy stopień, od którego człowiek zaczyna swe zaangażowanie miłosne, i na którym znajduje się, nie zawsze w pełni świadomie, od początku swego życia, to miłość cielesna. Kierując się tą miłością, człowiek pozostaje całkowicie skupiony na sobie i czyni wszystko ze względu na przemożną chęć zadowolenia siebie, a zwłaszcza swych cielesnych pożądań. Na drugi stopień człowiek wkracza, kiedy staje się zdolny do przenoszenia swojego uczucia miłosnego również na inne osoby i w konsekwencji kiedy zaczyna kochać Boga (Bernard zakłada bowiem, jak zobaczymy dalej, że każdy rodzaj miłości partycypuje w miłości Boga, ponadto podziału stopni miłości dokonuje w swoim traktacie ze względu na relacje do Niego). Miłość drugiego stopnia jest jednak nadal ograniczona ciągłym egoistycznym pragnieniem zaspokojenia przez człowieka przede wszystkim siebie samego. Choć więc kocha on już Boga, to jednak nadal „kocha Go ze względu na siebie”, spodziewając się od Niego jakiś darów przynoszących mu korzyść. Na trzeci stopień wkracza człowiek, gdy oczyszczając swe pragnienia i poznając Boga coraz lepiej, a więc krocząc drogą doskonałości duchowej, potrafi „kochać Boga ze względu na niego samego”, ze względu na to, kim On jest. Najwyższy wreszcie, czwarty stopień miłości możliwy jest do osiągnięcia w pełni dopiero w życiu eschatologicznym, kiedy człowiek całkowicie wyzwoli się z grzechu i całkowicie zapanuje nad swą naturą. Dopiero taki stan umożliwi mu całkowite zaangażowanie w miłosną relacje z Bogiem. Na tym etapie człowiek nie tylko kocha Boga całym sobą, ale również siebie samego i wszystko inne kocha ze względu na Niego. Eschatologiczność tego stanu nie zmienia faktu, że to na jego osiągniecie powinno być ukierunkowane nasze życie miłosno-duchowe. Tym bardziej, że już tu, w życiu doczesnym możemy go po części smakować dzięki doświadczeniu mistycznemu ${ }^{10}$.

10 Bernard z Clairvaux, O miłowaniu Boga, 23-28, w: Święty Bernard z Clairvaux, O miłowaniu Boga $i$ inne traktaty, tłum. S. Kiełtyka, Poznań 2000, s. 43-49. 
Stopnie miłości opisane w traktacie ukazują więc miłość jako coraz doskonalszą, o ile staje się ona coraz mniej pożądliwa i egoistyczna, a coraz bardziej ukierunkowana na Boga i coraz bardziej w tym akcie bezinteresowna, skupiona na Nim samym i na tym, czego on pragnie.

Podział z Pieśni nad Pieśniami nakłada się na ten z traktatu. Bernard nie omawia już jednak miłości cielesnej. Interesuje go jedynie ta miłość, którą przeżywa się, gdy wyruszyło się już w drogę doskonalenia duchowego, czyli miłość, która skłania nas do świadomego „szukania Boga”, co według Reguły Benedyktyńskiej jest celem życia monastycznego. Podział ten jest też dokładniejszy i, jeśli można tak powiedzieć, mniej abstrakcyjny niż przedstawiony we wcześniejszym traktacie. Mamy tu już nie trzy, ale pięć stopni miłosnej zażyłości z Bogiem, Bernard zaś posługuje się odniesieniem do różnych relacji miłosnych łączących nas z innymi ludźmi. Uzasadnia to kontekst: skoro najwyższy rodzaj miłości można najlepiej opisać językiem oblubieńczym - użytym nie dosłownie, ale alegorycznie - to również niższe jej rodzaje mogą być lepiej zrozumiałe dzięki zastosowaniu podobnego zabiegu. Wiąże się to też ze wspomnianym już przekonaniem, że każdy rodzaj miłości ziemskiej jest odblaskiem, znakiem i antycypacją miłości niebiańskiej.

A zatem najniższy rodzaj miłości to miłość niewolnika do swego Pana powodowana strachem przed nim. Następny to miłość najemnika do zwierzchnika oparta na chęci zysku. Obydwa one odpowiadają drugiemu stopniowi miłości z traktatu. Trzeciemu zaś kolejne dwa: pełna podziwu miłość ucznia do swego nauczyciela i oparta na poczuciu szacunku, bezpieczeństwa i troski miłość syna do ojca. Piątym, najwyższym rodzajem miłości - odpowiadającym czwartemu stopniowi, czy raczej wprowadzającym nań - jest już sama miłość oblubieńcza. Bernard charakteryzuje ją następująco:

Nie można znaleźć słodszych imion na nazwanie tego słodkiego przepływu uczuć pomiędzy Słowem i duszą niż Oblubieniec i Oblubienica. Pomiędzy nimi wszystko dzielone jest równo, nie ma egoistycznych zachowań, nic nie powoduje podziałów. Dzielą oni to samo dziedzictwo, ten sam stół, ten sam dom, to samo łoże małżeńskie. Są ciałem ze swego ciała. Dlatego opuści człowiek ojca i matkę i połączy się ze swą żoną i stają się jednym ciałem. Oblubienica zaś, ze swej strony, ma zapomnieć o swoim narodzie i domu swoich przodków, aby oblubieniec mógł się zakochać w jej piękności. A zatem, jeśli relacja miłości jest szczególną i wyróżniającą cechą oblubieńca i oblubienicy, 
nie jest niewłaściwe nazwanie duszy, która kocha Boga, oblubienicą. Ta, która prosi o pocałunek, jest zakochana. Nie prosi o szczodrość, ani o nagrodę, nie o dziedzictwo, ani nawet o wiedzę - ale o pocałunek. Jest to z pewnością prośba oblubienicy, która jest czysta, która oddycha miłością świętą - miłością, której żarliwości nie może całkowicie ukryć"11.

O ile więc wszystkie inne rodzaje miłości wiążą się z oczekiwaniem od drugiej osoby jakiejś korzyści materialnej, duchowej, czy choćby tylko zapewniającej poczucie bezpieczeństwa, o tyle miłość oblubieńcza podobnie jak miłość eschatologiczna $z$ traktatu jest całkowicie bezinteresowna. Oblubienica nie pragnie niczego poza samą osobą Oblubieńca, chce Jego intymnej, wyrażonej w pocałunku obecności, a nie czegoś, co mógłby on jej w swej szczodrości lub na znak miłości dać. Ponadto miłość oblubieńcza, pragnąc drugiej osoby, wyraża się też w całkowitym jej oddaniu. Dlatego właśnie jest ona w najwyższym stopniu wspólnotowa. Oblubieńcy niczego nie zatrzymują dla siebie, lecz wszystko, co mają i czym są, współposiadają, inaczej niż osoby związane niższymi rodzajami miłości, które pozostają zawsze w pewnej relacji podległości i związanej z tym „rozdzielności” posiadania.

W końcu Bernard wymienia jeszcze jedną cechę miłości oblubieńczej, w traktacie prawie niewidoczną: jest ona w swym pragnieniu zuchwała. W Pieśni nad Pieśniami zuchwałość ta wyraża się przede wszystkim w tym, że oblubienica prosi oblubieńca o pocałunek ust. Od tej prośby zresztą zaczyna się sama pieśń, jej pierwsze słowa to wołanie oblubienicy: „Niech mnie całuje pocałunkiem swoich ust!”. Dla Bernarda taki początek Pieśni jest z jednej strony zaskakujący, z drugiej zaś bardzo wymowny, o ile zwrócimy uwagę na to, co nam mówi o naturze miłości:

Zauważcie bowiem, jak nagle zaczyna swoją przemowę. Chcąc prosić o wielką łaskę ze strony wielkiej osoby, nie ucieka się tak jak inni do sztuki uwodzenia. Nie ucieka się do pokrętnych albo uniżonych zaczepek, aby osiągnąć nagrodę, której pragnie. Nie ma wstępu. Nie ma próby zyskania sobie łaski. Nie, ale ze spontanicznym wybuchem z obfitości swego serca, wprost, aż do zuchwałości mówi: Niech mnie całuje pocałunkiem swoich ust! Czyż to nie wydaje wam się

11 Cant. 7, 2, t. 1, s. 31-32. 
znaczyć, że pragnęłaby powiedzieć: Kogóż mam $w$ niebie oprócz Ciebie? I nie ma tė̇ nic na ziemi, czego pragnęłabym oprócz Ciebie ${ }^{12}$.

Dlaczego jednak wyrażone w sposób tak bezpośredni i spontaniczny pragnienie pocałunku ust Oblubieńca miałoby być ze strony oblubienicy oznaką zuchwałości? I co ta zuchwałość oznacza? Aby nam to wyjaśnić, Bernard zwraca uwagę, że istnieją różne rodzaje pocałunku: możemy wyróżnić pocałunek stóp, rąk i ust. Każdy z nich oznacza inny stopień bliskości i zażyłości łączący kochające się osoby. Można powiedzieć, że podział na rodzaje pocałunku to kolejny Bernardowy podział stopni miłości, wieńczący niejako te wcześniejsze ${ }^{13}$. Pierwsze dwa pocałunki składane są w sytuacji, gdy osoba miłująca jest w jakiś sposób podległa osobie kochanej, i to tylko ona je składa. Pocałunek nóg wyraża więc miłość pełną bojaźni i czci, jaką czuje w stosunku do swego Pana niewolnik czy najemnik. Pocałunek rąk wyraża z kolei miłość pełną szacunku i oddania, jaką czuje syn do swego ojca. Pocałunek ust natomiast składają sobie nawzajem osoby stojące na równych pozycjach. Wyraża on najgłębsze, najbardziej intymne zbliżenie między nimi, którego warunkiem niezbędnym jest równość osób. Domagając się pocałunku ust, oblubienica domaga się więc takiego wzajemnego zbliżenia, które wykracza poza relacje podległości i dystansu. Tymczasem ona jest przecież zwykłą pasterką, a On, zgodnie z opisami zawartymi w Pieśni nad Pieśniami, wielkim Panem czy wręcz pełnym majestatu królem. Wydaje się więc, że jedynie relacja miłosna budowana na podległości jest między nimi możliwa. Oblubienica dobrze zdaje sobie $\mathrm{z}$ tego sprawę, a jednak:

Nie mogę spocząć, odpowiada, jeśli nie pocałuje mnie pocałunkiem swoich ust. Dziękuję Mu za pocałunek stóp, dziękuję Mu także za pocałunek ręki. Jeśli jednak ma do mnie całkowity szacunek, niech mnie całuje pocałunkiem swoich ust. Nie ma z mojej strony żadnej niewdzięczności, po prostu jestem zakochana. Łaski, które otrzymałam, są o wiele większe, niż to, na co zasługuję, ale są mniejsze niż to, czego pragnę. To pragnienie popycha mnie naprzód a nie rozsądek. Proszę, nie oskarżajcie mnie o śmiałość. Jeśli poddaję się temu impulsowi miłości, mój wstyd rzeczywiście mnie napomina, ale miłość jest silniejsza od wszystkiego. Mam świadomość, że On jest królem, który kocha sprawiedliwość. Jednak zaślepiona miłość nie czeka na wyrok, żadna rada nie

Tamże.

Zob. tamże, 4, 1, t. 1, s. 18. 
skłoni jej do ustatkowania się, nie spęta jej wstyd ani nie opanuje rozum. Proszę, pragnę, błagam: Niech mnie całuje pocałunkiem swoich ust! ${ }^{14}$

Pragnienie oblubienicy jest zatem zuchwałe, bo w swej bezkompromisowości nie tylko nie ustępuje ona przed materialnymi i duchowymi przeszkodami, jakie stają jej na drodze do związania się z Oblubieńcem, ale nawet nie liczy się z fundamentalną przeszkodą, jaką jest brak równości wynikający $\mathrm{z}$ ich odmiennego statusu społecznego i majątkowego. Może dziś nie byłaby to przeszkoda fundamentalna, ale w czasach Salomona czy Bernarda bez wątpienia za taką ją uznawano. Aby w tej sytuacji otwarcie i w całej prostocie oblubieńczego pragnienia dążyć do miłosnego zbliżenia wykraczającego poza pełną dystansu cześć, trzeba było być zuchwałym, nie liczącym się z normami społecznymi i możliwością posądzenia o brak rozsądku, pychę lub zaślepienie. Tym, co zakochanych w tej sytuacji usprawiedliwia, zarówno w ich własnych oczach, jak i w oczach sławiących ich miłość poetów, w tym autora pieśni weselnej, jest wielki i bezkompromisowy żar miłości nie zważający nawet na tą, zdająca się czynić ich związek społecznie „niemożliwym”, przeszkodę:

Jest to żarliwa miłość, przez własny nadmiar ślepa na majestat ukochanego. Jakie bowiem są fakty? On jest Tym, na którego spojrzenie drży ziemia i czyż ona pragnie, by On dał jej swój pocałunek? Czy może jest pijana? Z pewnością pijana. A z jakiego powodu? Wydaje się najprawdopodobniejsze, że kiedy wypowiadała te pełne namiętności słowa, wyszła właśnie z piwnicy wina, bo później chwali się, że tam była. Dawid wołał także do Boga o ludziach takich jak owa oblubienica: Upija się obfitością Twojego domu i dasz im pić ze strumienia swojej rozkoszy. Jak wielka jest moc tej miłości?! Jak wielka ufność i wolność ducha?! Cóż bardziej oczywistego niż to, że lęk zostaje wygnany przez doskonałą miłośćm15.

Według Bernarda analogiczna sytuacja zachodzi w przypadku najwyższej miłości kierowanej przez dusze do Boga, co dostrzegamy, gdy przechodzimy ze znaczenia dosłownego tego opisu do jego znaczenia alegorycznego. Dusza popychana oblubieńczą miłością do Boga pragnie pokonać wszelkie bariery, które mogłyby oddzielić ją od umiłowanego. Wszelkie, a więc nie tylko te wynikające z grzechu czy poziomu jej doskonałości duchowej, ale również te najbardziej fun-

14 Tamże, 9, 2, t. 1, s. 43.

15 Tamże, 7, 3, t. 1, s. 32. 
damentalne, czyli wynikające $\mathrm{z}$ ich statusu ontycznego, z tego, że On jest Stwórcą i Panem, ona zaś kruchym stworzeniem. Jej miłosne pragnienie jest zuchwałe, bo w imię ontycznej dysproporcji i zależności, jaka między nimi istnieje, dusza w naturalny sposób powinna odczuwać wobec Niego bojaźń i drżenie, a jego Majestatowi okazywać cześć. Powinna zatem zadowolić się miłością okazywaną przez pocałunek Jego nóg czy rąk, co Bernard tłumaczy jako pełne pokory nawrócenie $\mathrm{z}$ drogi grzechu i oddawanie $\mathrm{Mu}$ chwały przez życie $\mathrm{w}$ cnocie $^{16}$. Domagając się zaś intymniej bliskości Boga, pocałunku jego ust - czyli kontemplacyjnego i miłosnego bycia z Nim twarzą w twarz - dusza najwyraźniej tych uczuć $\mathrm{Mu}$ nie okazuje. Czyni tak jednak nie z ignorancji lub pychy prowadzącej duchy upadłe do grzesznej „uzurpacji boskości”, lecz z powodu miłości ${ }^{17}$. Wyjątkowość, a nawet w pewnym sensie boskość i doskonałość tego uczucia, polega właśnie na tym, że pozwala ono wznieść się ponad wszelkie wynikające $\mathrm{z}$ ich nierówności przeszkody tworzące barierę między nimi. Dlatego uczucia i stany ducha właściwe na niższych stopniach doskonalenia duchowego i decydujące o naszym sposobie odnoszenia się do Boga, jak bojaźń najemnika czy cześć synowska, zostają na tym najwyższym stopniu miłości przekroczone. Należą się one Bogu jako Panu i Ojcu, ale już nie jako Oblubieńcowi:

Od miłowania przecież, a nie od oddawania czci, miłość bierze swą nazwę. Zaiste niech oddaje cześć ten, kto się boi, kto jest pełen osłupienia, lęku i podziwu, lecz w odniesieniu do tego, który kocha wszystko to przestaje obowiązywać. Miłość sam sobie wystarcza. Miłość, tam gdzie nastaje, zwycięża i ujarzmia wszystkie inne uczucia. Dlatego też to, co kocha, po prostu kocha, i nie uznaje niczego więcej. I z tego właśnie powodu nawet Ten, który tak zasłużenie jest czczony, który słusznie wprawia w osłupienie i słusznie budzi podziw, nawet On woli jednak być kochany. On więc jest Oblubieńcem, a dusza oblubienicą. Jakiego innego rodzaju związku czy raczej innego rodzaju połączenia [zjednoczenia] szukasz między oblubieńcami, niż tego, który polega na kochaniu i byciu kochanym?"18.

Wyzbyta strachu przed Boskim majestatem zakochana dusza nie chce już usatysfakcjonować się żadnym rodzajem zbliżenia z Nim, które zachowując pe-

\footnotetext{
16 Zob. tamże, 4,1, t. 1, s. 18.

17 Zob. tamże, 4, 3-4, t. 1, s. 19-20.

18 Tamże, 83, 3, t. 2, s. 300.
} 
wien dystans byłoby odpowiednie dla jej marnej kondycji stworzenia. Wbrew temu, co dla niej odpowiednie, zuchwale dąży do zbliżenia, w którym tego dystansu nie będzie. Wciąż powtarza, że pragnie „pocałunku jego ust”, a nie innych możliwych rodzajów pocałunku, które mógłby jej ofiarować. Sam zaś Bóg, jako Oblubieniec, zamiast ją skarcić, wręcz ją do tego zuchwałego pragnienia zachęca:

Jeżeli nawet prawdą jest, iż cześć króla kocha sprawiedliwość (Ps 98, 4), to jednak miłość oblubieńca, czy raczej Oblubieńca, który jest miłością, szuka jedynie wzajemnej miłości i ufności. Dąży do tego, by ukochana odpowiedziała miłością na jego miłość. Jakże więc mogłaby nie miłować oblubienica, i to oblubienica Miłości? Jakże nie miłować Miłości? Słusznie zatem wyrzekając się wszystkich innych uczuć, oddaje się jedynie i całkowicie miłości, tak że właśnie w odwzajemnieniu miłości znajduje właściwą odpowiedź na miłość"19.

\section{Miłosna transgresja norm}

Miłość oblubieńcza jest więc wedle Bernarda zuchwała i bezkompromisowa w swym dążeniu do najbardziej intymnego zjednoczenia $\mathrm{z}$ drugą osobą. Można ją zatem także określić jako transgresyjną. To współczesne wyrażenie, używane tak często na gruncie kultury i filozofii, bardzo dobrze oddaje jej charakter.

Przez transgresję (od łac. transsgresio, czyli dosłownie: przejście, przekroczenie) rozumie się przekroczenie granic wyznaczanych przez jakieś normy, np. prawne, społeczne, moralne czy estetyczne ${ }^{20}$. Gdy ktoś świadomie i manifestacyjnie ubiera się czy zachowuje niezgodnie z uznanymi w danym społeczeństwie zasadami, dokonuje ich transgresji. Gdy artysta manifestacyjnie przełamuje w swych dziełach przyjęte dotąd kanony piękna, jego sztuka jest odbierana jako transgresywna. Podobnie miłość oblubieńcza, tak jak ją ukazuje Pieśń nad Pieśniami i jak ją interpretuje Bernard, zmierzając w swej bezkompromisowości do przełamania wszelkich barier uniemożliwiających jej spełnienie, transgresywnie przekracza w końcu również te, które w oparciu o przyjęte normy decydują, że takie miłosne zjednoczenie nie jest możliwe. W życiu kochanków z biblijnej

19 Tamże 83, 5-6, t. 2, s. 301-302.

20 Słownik języka polskiego. T. 1, A-K, red. tomu Hipolit Szkiłądź, s. 486. Por. S. Ślaski, Zachowania transgresyjne - próba psychologicznego pomiaru, „Przegląd Psychologiczny”, 2010, t. 53, nr. 4, s. $401-416$. 
pieśni ta transgresja dokonuje się na poziomie norm społecznych i obyczajowych wyznaczających granice związku miedzy osobami o innym statusie społecznym, do czego miłość oblubieńcza nie chce się dostosować. Oblubieńcza transgresja w życiu duchowym i mistycznym dokonuje się natomiast na polu norm metafizycznych, a do pewnego stopnia także teologicznych. Tym bowiem, co stanowi największą barierę w miłosnym zjednoczeniu duszy i Boga, jest ich odmienny status ontyczny: ona jest bytem przygodnym, On - bytem absolutnym. Normą zaś dominująca $\mathrm{w}$ myśli zachodniej było podkreślanie nieprzekraczalności tej bariery.

Norma ta ma swój fundament jeszcze w zasadach metafizyki greckiej wypracowanych głównie na gruncie arystotelizmu, lecz z czasem zaakceptowanych i rozwijanych $w$ innych szkołach filozoficznych. Zgodnie z nimi istota każdego bytu jest ściśle określona przez jego formę oraz specyficzne dla niej niezbywalne cechy, doskonalenie polega zaś na aktualizowaniu całego potencjału tej bytowej istoty, wypełnieniu jej formy, która sama w sobie pozostaje niezmienna. Zmiana polegającą na przekroczeniu ontycznej granicy, którą wyznacza istota, nie była wedle Greków ani możliwa, ani potrzebna, oznaczałaby bowiem wejście w niedoskonałość, czyli w przypadku bytów niższych, np. człowieka unicestwienie, a nie spełnienie, zaś w przypadku Absolutu utratę całkowitej niewzruszoności, monolityczności i tym samym boskości. Zasadą metafizyczną, a w konsekwencji też regułą etyczną, było więc nieprzekraczanie właściwej miary doskonałości bytu, ściśle określonej przez jego istotę nadającą mu tożsamość i decydująca o jego pozycji w hierarchii bytów ${ }^{21}$.

Teologia chrześcijańska przyjęła za dobrą monetę ten aspekt metafizyki greckiej, wydawał się on bowiem dobrze odpowiadać kategoriom monoteizmu przekazywanego przez starotestamentowe Objawienie i podkreślającego transcendencję Boga wobec stworzenia. Transcendencja ta ustanawiała między człowiekiem a Bogiem nawet nie granicę, ale wręcz przepaść ontyczną, która z kolei nie powalała przypisywać ludziom, zwierzętom ani jakiemukolwiek stworzeniu

${ }_{21}$ Zob. G.S. Kirk, J.E. Raven, M. Schofield, Filozofia przedsokratejska, tłum. J. Lang, Warszawa 1999, s. 190, 202, 251-254; Arystoteles, Metafizyka, Z, 4-12, H, 2-3; Fizyka, Г, 6, 207 a 15. Por. tamże, B, 7-8. Por też. J. Taubes, Hegel, „Kronos” 2014, nr 4, s. 135-136; W. Jaeger, Paideia, tłum. M. Plezia i H. Bednarek, Warszawa 2001, s. 479; G. Reale, Historia filozofii starożytnej, t. 1, tłum. E.I. Zieliński, Lublin 1999, s. 47; tamże t. 2, s. 364 . Więcej na ten temat piszę w: Idea transformacji natury ludzkiej w myśli patrystycznej i średniowiecznej, w: Fenomen tego, co nadchodzi, Poznań 2020, s, 104-107, 119-120. 
żadnego „stopnia” boskości, tak jak to czyniono na gruncie religii pogańskich. Skłaniało to wielu teologów do podkreślania nieprzekraczalności ontycznej granicy dzielącej człowieka i Boga i traktowania tej zasady jako miary teologicznej ortodoksji, poza którą popadało się ich zdaniem w panteistyczną czy politeistyczną uzurpację boskości ${ }^{22}$.

Istniała, co prawda, od początku w myśli chrześcijańskiej, a zwłaszcza w jej nurcie wschodnim, rozwijającym pewne intuicje filozofii neoplatońskiej (głoszącej, że człowiek wypełnia swe najgłębsze powołanie, dążąc do zjednoczenia z Absolutem, ale czyniąc to za cenę przyznania duszy ludzkiej statusu boskiego), tendencja, by w imię prawdy o Wcieleniu i jej antropologicznych konsekwencji, podważać metafizyczną niezmienność i konieczność istot ${ }^{23}$. Bóg bowiem, jak podkreślano, stał się człowiekiem właśnie po to, aby człowiek mógł stać się Bogiem $^{24}$. Co więcej, uważano, że właśnie ze względu na to niezwykłe przeznaczenie człowiek został uczyniony na obraz i podobieństwo swego Stwórcy. Choć więc nie jest on bogiem ze swej natury, to jednak jest powołany do „przebóstwienia" tej natury i przekroczenia jej stworzonych uwarunkowań ${ }^{25}$.

Ta rozwijana w patrystyce wschodniej tendencja do zasypywania ontycznej przepaści miedzy Absolutem a stworzeniem była jednak na łacińskim Zachodzie mocno tonowana i wyciszana w imię monoteistycznej gorliwości i ostrożności, nawet na gruncie tak bliskiego filozofii neoplatońskiej augustynizmu, a z czasem stała się wręcz teologicznie podejrzana. Teolodzy, którzy do niej nawiązywali, tacy jak Eriugena, musieli borykać się z oskarżeniami o przekroczenie stosownej teologicznej „miary”. Zarazem trzeba przyznać, że kwestia ta długo pozostawała daleka od jednoznaczności. Paradoksalnie bowiem w głównym nurcie teologii zachodniej, jakim do XII wieku była uprawiana w klasztorach teologia monastyczna, żywych było wiele integralnych elementów tej patrystycznej wizji, zwłaszcza koncepcja stworzenia człowieka na obraz i podobieństwo, która stano-

22 Zob. np. na temat konsekwencji postanowień Soboru w Nicei w: A. Louth, Początki mistyki chrześcijańskiej, tłum. H. Bednarek, Kraków 1997, s. 99-105.

23 Zob. E. Gilson, Duch filozofii średniowiecznej, tłum. J. Rybałt, Warszawa 1958, s. 347.

24 Św. Atanazy, De Incarnatione Verbi, 54, 3, PG 25, 192. W tym właśnie zapisie jest zazwyczaj cytowane owo słynne sformułowanie Atanazego, inaczej więc niż w polskim tłumaczeniu: zob. Atanazy z Aleksandrii, O wcieleniu Słowa, tłum. M. Wojciechowski, Warszawa 1998, s. 73. Por. E. des Places, Divinisation. Pensée religieuse des Grecs, w: Dictionnaire de spiritualité ascétique et mystique, t. 3, kol. 1370-1375; G. Bardy, Divinisation. Chez les Pères Latin, w: tamże, kol. 1389-1398.

25 Zob. M. Coune, Grace de la Transfiguration d'apres les Peres d'Occident, Bellefontaine 1990. 
wiła dla Ojców, tak jak później dla Bernarda, jeden z ważniejszych antropologicznych argumentów przemawiających za niezwykłym, „boskim” przeznaczeniem człowieka. Dlatego też w teologii monastycznej, inaczej niż później w scholastyce, nie oddzielano od siebie i nie przeciwstawiano sobie tego, co naturalne i nadnaturalne, uznając, że granica między tymi stanami jest płynna, gdyż natura zawsze rozwija się w perspektywie łaski ${ }^{26}$. Ostatecznie jednak zarówno rzymski, „prawniczy” duch dążący do wyznaczania jasnych granic tego, co i komu wolno, jak pamięć walk z panteistycznymi herezjami, oraz też zapewne wiele innych przyczyn historycznych i kulturowych sprawiło, że na średniowiecznym Zachodzie w tak fundamentalnej kwestii, jak określnie najwyższej dostępnej człowiekowi doskonałości, bardziej dmuchano na zimne niż dawano się ponieść żarowi Ojców. Granica między tym, co stworzone, i tym, co boskie, pozostawała jasno i zdecydowanie określona, a kwestii jej „przekroczenia” raczej nie podejmowano, co miało konkretne konsekwencje dla duchowości i mistyki. Gdy więc na gruncie teologii zachodniej mówiono o duchowej bliskości człowieka i Boga, podkreślano zazwyczaj jej wymiar uczuciowy, poznawczy, wolitywny, ale już nie ontyczny. Gdy zaś ukazywano ostateczne, eschatologiczne przeznaczenie człowieka, którego antycypacją jest doświadczenie mistyczne, opisywano je zazwyczaj w kategoriach widzenia Boga czy radowania się duchowymi darami otrzymanymi od Niego, ale raczej nie posuwano się dalej w kwestii jedności z Nim. Akcentowano więc taki rodzaj bliskości, która owszem, pozwalała człowiekowi cieszyć się Bogiem, ale niejako $\mathrm{z}$ „zewnątrz", zachowując wobec Niego pewien dystans i nie narażając w niczym Jego wynikającego $\mathrm{z}$ ontycznej transcendencji majestatu ${ }^{27}$.

A zatem z perspektyw klasycznej metafizyki podarowującej zachodniej teologii właściwa „miarę” stosunku człowieka do Boga uwypuklanie przez Bernarda tego, że miłość oblubieńcza stanowiąca najwyższy etap duchowego doskonalenia, do którego powołany jest człowiek, z natury swej bezkompromisowo dąży do możliwie pełnego zjednoczenia duszy $\mathrm{z}$ boskim Oblubieńcem, i tym samym zmierza do transgresyjnego przekroczenia wszelkich uniemożliwiających to zjednoczenie barier, również tych wypływających $\mathrm{z}$ ich odmiennego statusu ontycznego, wydaje się wysoce niestosowne i nierozsądnie, ocierające się wręcz o niemożliwe. Dlatego można powiedzieć, że w cytowanych wyżej słowach z Ber-

26 R. Javelet, Image et ressemblance au douzième siècle. De saint Anselme à Alain de Lille, Paris 1967, t. 1, s. 322-343.

27 Por. G. Bardy, Divinisation. Chez les Pères Latin, dz. cyt, kol. 1389-1398; M.A. Fracheboud, Divinisation. Auteurs monastique..., kol. 1399-1431. 
nardowego komentarza, w których oblubienica przyznaje, że w swym dążeniu nie liczy się z majestatem Oblubieńca, jej zuchwałość wobec rodziny i przyjaciół oskarżających ją o brak rozsądku i wstydu przekłada się na mistyczną i teologiczną zuchwałość samego Bernarda wobec „norm” teologii Zachodniej. Zuchwałość, która dla tego filara ortodoksji, gotowego bronić jej przed różnymi heterodoksyjnymi zagrożeniami, oznaczało „nierozsądne” balansowanie na granicy ortodoksji.

Bernard nie czynił tego jednak w imię teologicznej prowokacji. Wydobycie cech bezkompromisowości, a tym samym transgresyjności miłości oblubieńczej było konsekwencją jego doświadczenia duchowego oraz niezwykle głębokiego wniknięcia w misterium chrześcijańskie. Konsekwencji tej poświęcił tyle miejsca w swych mistycznych pismach, bo fascynowała go ona i pociągała. $\mathrm{Z}$ drugiej jednak strony była dla niego wyraźnie kłopotliwa, trudna do wyrażenia, wręcz budząca lęk swą dogmatyczną i duchową niejednoznacznością. Lęk ten niejednokrotnie wyrażał w komentarzach. Na przykład wtedy, gdy pisząc o zuchwałym pragnieniu oblubienicy, by otrzymać od Boga pocałunek ust, zwracał się do słuchaczy, a także w pewnym sensie do siebie samego: „z pokorą odważymy się wznieść nasze oczy ku Jego ustom, tak pięknym, nie tylko by na nie patrzeć, ale - mówię to z drżeniem i lękiem - by otrzymać ich pocałunek"28.

Bernard bowiem nie miał zamiaru negować istnienia ontycznej przepaści oddzielającej człowieka od Boga. Zdecydowanie podkreślał, że „człowiek jako taki, nic w sobie z natury boskiej nie posiada" ${ }^{29}$. Transcendencja Stwórcy wobec stworzenia, a tym samym „nie-boski” charakter człowieka były dla niego niepodważanym fundamentem chrześcijańskiej teologii. W imię tej ontycznej dysproporcji i zależności, jaką ona rodzi, człowiek powinien w naturalny sposób odczuwać wobec Boga bojaźń, a jego Majestatowi okazywać cześćc ${ }^{30}$. Jeżeli jednak wznosząc się na drodze duchowego doskonalenia jej nie okazuje, to nie z powodu ignorancji lub pychy. Tak jak miłość oblubieńcza łącząca ziemskich kochanków usprawiedliwia ich i pozwala im na przekraczanie swych pozycji społecznych, tak miłość oblubieńcza łącząca człowieka i Boga, usprawiedliwia i umożliwia przekraczanie przepaści ontycznej dzielącej stworzenie do Absolutu: „Więź ta bowiem pokonuje nawet to, co z taką siłą spaja natura, czyli owe więzy, które łączą rodziców z ich

$28 \quad$ Cant. 3, t. 5, t. 1, s. 17.

29 „[H]omo purus, nihil de natura divinitatis habens". Sermo in festivitate Sancti Martini episcopi, w: Sancti Bernardi Opera, t. 5, s. 399-412.

30 Tamże 83, 4, t. 2, s. 300 . 
dziećmi. Dlatego właśnie, jak mówi Pismo, opuści człowiek ojca swego i matkę swoją i złączy się z oblubienicą (Mt 19, 5). Chyba widzicie już, jak silne jest uczucie, które wiąże oblubieńców - silniejsze nie tylko od innych uczuć, ale i od samego siebie"31. Na tyle silne, że mimo iż dusza jest słabym stworzeniem, „jeńcem na wygnaniu, uwięzionym w ciele, grzęznącym w błocie"32, wprowadza ją do komnaty Oblubieńca, „gdzie może oglądać Boga w niezmąconym spokoju, gdzie nie jest On ani Sędzią, ani Nauczycielem, lecz Oblubieńcem" ${ }^{33}$, i gdzie w końcu, wbrew czyniącym jej wyrzuty normom metafizycznym dane jest jej doświadczyć „małżeńskiego zjednoczenia z boskim małżonkiem" ${ }^{34}$.

\section{Transgresja i przebóstwienie}

Na oznaczenie zjednoczenia duszy i Boga Bernard najczęściej używa sformułowania zaczerpniętego od św. Pawła: jedność duchowa (unitas spiritus) ${ }^{35}$. Wedle Apostoła jest ona na poziomie duchowym tym, czym jedność cielesna jest dla osób związanych węzłem małżeńskim. Do tego sformułowania i stojącej za nim analogi odwołuje się Bernard np. w cytowanym wyżej kazaniu, w którym ukazywał oblubieńcze pragnienie pocałunku ust Boga, czyli bezpośredniego, intymnego zbliżenia z Bogiem:

Szczęśliwa dusza, której dane jest doświadczyć tak rozkosznego zjednoczenia! Jest to bowiem nic innego, jak miłość święta i czysta, pełna słodyczy i radości, miłość całkowicie niezmącona i wierna, wzajemna i głęboka, która łączy dwie istoty nie w jednym ciele a w jednym duchu, sprawiając, że nie są już dwoje, lecz jedno (Mt 19, 5). Tak jak powiada Paweł: Kto łączy się z Bogiem, jest $z$ Nim jednym duchem $\left(1\right.$ Kor 6, 17) ${ }^{36}$.

Samo użycie sformułowania unitas spiritus na oznaczenie zjednoczenia człowieka i Boga nie stanowiło ze strony Bernarda aktu teologicznie ryzykownego.

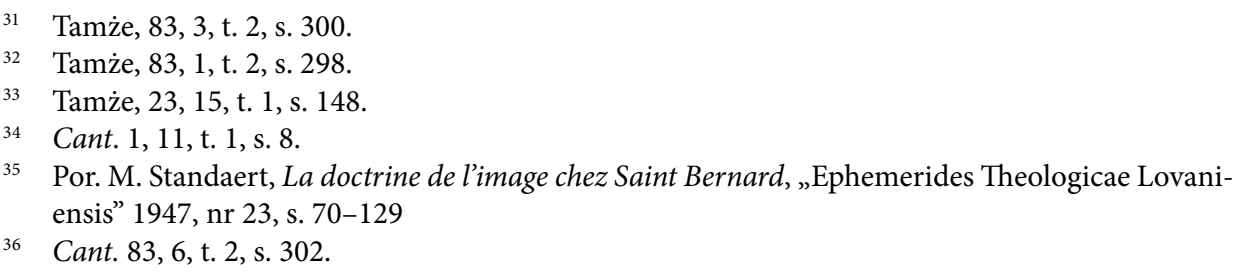


Sformułowanie to było znane i uznane na terenie zachodniej duchowości ${ }^{37}$. Odwoływano się do niego chcąc ukazać wykraczającą poza „ogląd” i „dar” wyjątkowość mistycznej biskości człowieka i Boga. Z perspektywy monoteistycznej ostrożności wydawało się ono w takim wypadku dość bezpieczne, gdyż było potwierdzone autorytetem Pawła, jak też dlatego, że określenie tej jedności jako „duchowej” pozwalało interpretować ją jako dokonująca się w sferze działań i pragnień duchowych, a nie na poziomie ontycznym.

Podobnie Bernard, mówiąc o „unii duchowej” łączącej duszę i Boga, wielokrotnie podkreśla, że nazywa ją „duchową”, gdyż różni się ona od „jedności substancjalnej”, charakteryzującej doskonałe zjednoczenie Osób w Bogu. W przypadku duszy i Boga zjednoczenie to dokonuje się bowiem na mocy zgodności woli, które pragną tego samego, a nie na mocy tożsamości substancjalnej, jak w przypadku osób Boskich. Temu rozróżnieniu Bernard poświęca prawie całe kazanie siedemdziesiąte pierwsze ${ }^{38}$. W ten sposób zdecydowanie odżegnuje się od obecnej w platonizmie i gnozie koncepcji tożsamości ontycznej człowieka i Boga, zgodnie z którą dusza jednoczyła się z Absolutem i roztapiała w Nim, gdyż w swej boskiej istocie stanowiła jego cześć. Można jednak odnieść wrażenie, że jest to $\mathrm{z}$ jego strony rodzaj asekuracji wobec tego, co sam na temat jednoczącego charakteru mistycznej miłości pisze w innych miejscach. Bernard nie miał bowiem zamiaru negować dogłębnego wpływu tej jedności na bytową strukturę człowieka. Widać to np., gdy pisze o unii duchowej w traktacie O rozważaniu: „Bóg jest w nas w ten sposób, że dokonuje w nas dobra, wlewa je w nas, albo raczej trzeba powiedzieć, że sam się nam udziela i daje, do tego stopnia, iż bez obawy można mówić, że jest z nami jednym duchem, jakkolwiek nie stanowi z nami jednej osoby i jednej substancji" 39 .

Jednak nade wszystko świadczą o tym najbardziej znane i żarliwe Bernardowe opisy mistycznej unii, w których podkreśla, że siła miłosnego przylgnięcia jest tak wielka i bezgraniczna, iż dochodzi w niej nie tylko do jedności woli człowieka i Boga, ale też do pewnego - będącego raczej procesem niż stanem - zjednoczenia ich natur, które nie unicestwiając ich odrębności, pozwala im się przenikać, co przynajmniej w przypadku natury ludzkiej prowadzi do głębokiego, sięgającego

\footnotetext{
Zob. R. Javelet, Image et resemblance..., dz. cyt., t. 1, s. 439.

Zob. Cant. 71, t. 2, s. 214-224.

39 Bernard z Clairvaux, O rozważaniu, 5, 12, w: Święty Bernard z Clairvaux, O miłowaniu Boga $i$ inne traktaty, tłum. S. Kiełtyka, Poznań 2000, s. 232-233.
} 
samej jej istoty przeistoczenia ${ }^{40}$. To przeistoczenie polega na przejęciu pewnych cech natury Boskiej, określanym w terminologii wschodniej jako przebóstwienie. Bernard niejednokrotnie używał tego właśnie terminu, choć na Zachodzie z ukazanych wyżej względów zdecydowanie się jej wystrzegano ${ }^{41}$.

Tak jest np. w znanym fragmencie z traktu $O$ miłowaniu Boga, opisującym czwarty, najwyższy stopień miłości, w którym Bernard wyraźnie odwołuje się do kategorii przebóstwienia, a zarazem, chcąc oddać jak najplastyczniej to, co się w tym stanie dokonuje, używa - zapośredniczonych najprawdopodobniej również od Ojców wschodnich - neoplatońskich metafor dotyczących mistycznej jedność z Absolutem:

O, miłości czysta i święta! Słodkie uczucie rozkoszy! Tęsknoto porywająca i wspaniała! Tym bardziej wzniosła i wspaniała, że daleka od przywiązań ziemskich, tym słodsza i bardziej niebiańska, że napełniona boskością (totum divinum). Przeżywać to, znaczy - doznawać przebóstwienia (Sic affici, deificari est). Jak maleńka kropelka wody, wlana do wielkiego naczynia z winem, rozpływa się w nim bez śladu, przyjmując jego smak i kolor; jak kawałek żelaza, wrzucony do ognia, traci swą postać i staje się ogniem; jak powietrze pod działaniem promieni słońca nie tylko jest przejrzyste, ale samo staje się światłem - podobnie ziemskie uczucia świętych w nieprzenikniony sposób rozpłyną się i złączą niepodzielnie $z$ wolą Bożą: w przeciwnym razie, jakżeby Bóg był wszystkim we wszystkim (1 Kor 15, 28), gdyby w człowieku zostało cokolwiek z człowieka? Pozostanie wprawdzie istota (substantia), ale w innym kształcie (in alia forma), w innej chwale, w innej mocy ${ }^{42}$.

Według Bernarda zatem jedność, której doświadcza człowiek w mistycznej unii z Bogiem - zapowiadającej i antycypującej jego stan ostateczny - nie wyczerpuje się tylko w jedności poznawczej czy uczuciowej, lecz przechodząc przez nie sięga do samych korzeni bytu - tam, gdzie formuje się jego ludzka tożsamość. W konsekwencji tej jedności człowiek doświadcza przemiany gdyż jednoczy się z doskonałościami bytu Boskiego, które go dosłownie przenikają i przemieniają. Nie ulega wprawdzie unicestwieniu, jego substancja pozostaje, ale nabiera nowego kształtu, nowej formy bycia.

40 Zob. R. Javelet, Image et resemblance..., dz. cyt., t. 1, s. 440-443

41 Por. M.A. Fracheboud, Divinisation. Auteurs monastique..., dz. cyt., kol. 1405-1407; E. Gilson, La théologie mystique de saint Bernard, dz. cyt., s. 41. 
Innym miejscem, w którym Bernard mówi wyraźnie o przebóstwieniu, jest Kazanie „Na oktawę Wniebowzięcia Najświętszej Maryi Panny”. Czyni to, gdy opisuje stan natury ludzkiej w Chrystusie, a więc zjednoczonej z jego natura Boską. Co ciekawe, stosuje tu rozróżnienie takie jak w przypadku unitas spiritus. Zastrzega, że deificatio nie zamienia substancji człowieka, lecz jego uczucia, czy szerzej - usposobienie: „Człowieczeństwo wydaje się być pochłonięte przez Bóstwo nie dlatego, iżby zmieniła się substancja, ale ponieważ ubóstwione zostało jego całe Jego usposobienie (non quod sit mutata substantia, sed affectio deificata)"43. Wydaje się, że tym razem bardziej zależało mu na byciu dobrze zrozumianym na gruncie teologii zachodniej niż na transgresyjnym poszerzeniu jej kategorii. Nie oznacza to jednak, że Bernard, stosując tego typu rozróżnienie w przypadku deificatio, wycofał się z ukazanej wyżej, zdecydowanie wschodniej w swym wyrazie, wizji przebóstwienia. Kontekst, w jakim to mówi, czyli kwestia przebóstwienia natury ludzkiej w Chrystusie, wskazuje, że w rozróżnieniu na substania i affectio chodzi mu przede wszystkim o podkreślenie, iż w Chrystusie nie dochodzi do unicestwienia ludzkiej natury, a nie o to, że stan ten dotyka tylko tego, co w człowieku przypadłościowe i drugorzędne, nie sięgając i nie przemieniając jego ontycznych korzeni, co kłóciłoby się z obrazem przebóstwienia człowieczeństwa Chrystusa, jaki zostawiły Ewangelie. Potwierdzenie tego zyskujemy, analizując sposób, w jaki Bernard charakteryzuje stan natury ludzkiej w zjednoczeniu mistycznym, gdy komentuje Pieśń nad Pieśniami.

W Kazaniach do Pieśni nad pieśniami nie znajdujemy terminu deificare, być może uznanego w tym czasie Bernarda za zbyt kłopotliwe, jednak właśnie o stanie przebóstwienia jest tam wciąż mowa. Opat mówi o nim językiem oblubieńczym, gdy opisuje mistyczne zaślubiny duszy z Bogiem. Podczas zaślubin tych, jak pamiętamy, dochodzi między duszą - oblubienicą a boskim Oblubieńcem do analogicznego intymnego zbliżenia jak między ludzkimi kochankami. Tak jak w sypialni ludzcy oblubieńcy stają się jednym ciałem, tak w „sypialni Boga” Stwórca i dusza stają się jednym duchem ${ }^{44}$. To, że w unitas spiritus dochodzi nie tylko do przypadłościowego uzgodnienia woli człowieka z wolą Boga, lecz że jedność ta sięga samej istoty, samej struktury ontycznej człowieka, że dochodzi właś-

\footnotetext{
43 Bernard z Clairvaux, Kazania na Wniebowzięcie Najświętszej Maryi Panny, 1, w: Św. Bernard z Clairvaux, Kazania o Najświętszej Maryi Pannie, tłum. I. Bobicz, Warszawa 2000, s. 156.

44

Cant. 23, 14-16, t. 1, s. 148-149.
} 
nie do jego przebóstwienia, możemy zobaczyć na przykładzie trzech sposobów, w jakie Bernard je opisuje, za każdym razem zmieniając trochę perspektywę.

Przede wszystkim często podkreśla on bezpośredniość i niezwykłą intymność tego zjednoczenia ${ }^{45}$. Nawet jeśli dokonuje się ono dzięki miłosnemu zjednoczeniu woli, to wyraźnie prowadzi do „przylgnięcia” bytu ludzkiego i Boskiego, co nie byłoby możliwe bez przekroczenia dzielącego je ontycznego dystansu:

Podczas tych świętych zaślubin zawierany jest prawdziwie duchowy związek. Za mało nawet powiedzieć „Związek” (contractus), raczej należałoby mówić o „przylgnięciu” (complexus). Przylgnięcie całkowite, takie, w którym ta sama wola czegoś i ten sam brak woli względem czegoś, czyni dwoje jednym duchem $(1 \text { Kor } 6,17)^{346}$.

Warto dodać, że w jednym ze swych kazań napisanych na inną okazje, Bernard określa to przylgnięcie wręcz jako prowadzące do wzajemnego zespolenia człowieka i Boga (copulatio), a następnie podkreśla, że jedność ta jest „współprzenikającą" (interpenetrante) ${ }^{47}$.

Mistyczne zjednoczenie pozwala też człowiekowi poznawać Boga bez żadnych pośredników, substytutów czy pojęć, czyli poznawać go doświadczalnie, twarzą w twarz. Ale to nie wszystko. Według Bernarda człowiek w tym stanie nie tylko poznaje bezpośrednio Boga, lecz poznaje Go, a w Nim i siebie, tym typem poznania, jaki przysługuje tylko Bogu. Innymi słowy, przyjmuje doskonałość Jego bytu, ma w nim udział. Dotyczy to zresztą nie tylko poznania, lecz też innych aktów duszy, a zwłaszcza miłości:

Kiedy więc przyjdzie to, co doskonałe, wówczas ustąpi to, co częściowe (1 Kor $13,10)$, a ich połączy czysta i spełniona miłość, pełne poznanie, jasne widzenie $(1 \mathrm{Krl} 3,1)$, silny związek, niepodzielna wspólnota, doskonałe podobieństwo. Wtedy dusza będzie poznawać tak, jak sama jest poznawana (1 Kor, 13, 12), wtedy też będzie kochać tak, jak sama jest kochana, i rozraduje się Oblubieniec swą oblubienicą, poznający i poznawany, kochający i kochany (Iz 62, 5), Jezus Chrystus, nasz Pan, który ponad wszystko jest Bogiem błogosławionym na wieki" ${ }^{\prime 4}$.

45 Por. R. Javelet, Image et ressemblance..., dz. cyt., t. 1, s. 456-457.

46 Cant. 83, 3, t. 2, s. 299.

47 Zob. Bernardus Claraevallensis, Sermones in dedicatione ecclesiae, 2, 7, w: SBO, ed. J. Leclercq, H.M. Rochais, Romae 1968, t. 5, s. 380. Por. R. Javelet, Image et ressemblance ..., dz. cyt., t. 2, s. 315. 
W końcu według Bernarda w miłosnym zjednoczeniu, kiedy to człowiek poznaje i kocha tak jak Bóg, dochodzi do jego przemiany, dosłownie do transformacji (transformatio) ${ }^{49}$. Jak bowiem podkreśla w kazaniu 71, tym samym, w który rozróżnia jedność substancjalną i jedność usposobienia, gdy człowiek zostaje zjednoczony ze Słowem - unior, zostaje też w swym jestestwie do Niego dostosowany - conformor i w konsekwencji tego dostosowania zostaje przez Słowo przekształcony - transformor ${ }^{50}$. Podobnie unię z Bogiem opisuje w kazaniu 62: „Zostajemy [przez Boga] przemienieni, skoro zostajemy [z Nim] uzgodnieni (transformamur cum conformamur)" 51 . O przekształceniu formy mówił Bernard, jak widzieliśmy, już wtedy, gdy opisywał przebóstwienie w traktacie o miłości: deificatio nie zmienia naszej substancji, nie unicestwia nas jako odrębnych bytów, ale nadaje nowy kształt naszej formie (alia forma). W Kazaniach deificatio jeszcze wyraźniej ukazane jest jako dokonujące się na płaszczyźnie naszej formy substancjalnej. Dla Bernarda bowiem conformatio i transformatio to sformułowania, które mają swoje odpowiedniki odnoszące się do innych ontycznych stanów człowieka. Bóg, stwarzając człowieka, uformował go - formatio, gdy zaś człowiek w wyniku grzechu upadł, doszło do zepsucia jego natury - deformatio, zbawcza łaska zaś, umożliwiając mu odnowienie, prowadzi do jej naprawy - reformatio. Dopiero po przejściu tego etapu człowiek może wejść na drogę doskonalenia prowadzącą go do ostatecznego spełnienia jego powołania, jakim jest miłosne przylgnięcie do Boga, a w konsekwencji właśnie jego conformatio i transformatio ${ }^{52}$. We wszystkich tych stanach, które są wynikiem duchowej i egzystencjalnej

49 Bernard, mówiąc o transformatio człowieka, wyraźnie odwołuje się do stwierdzenia św. Pawła $\mathrm{z}$ listu do Koryntian, w tłumaczeniu Wulgaty, wedle którego wpatrując się w chwałę Boga, „zostaniemy przemienieni na Jego obraz” [in eamdem imaginem transformatur] (2 Kor 3, 18). W tym kontekście jako ogólnie pojętej przemiany kondycji ludzkiej w stanie eschatologicznym używano tego pojęcia na Zachodzie, jednak raczej aby zastąpić niebezpieczne pojęcie deificatio niż je z nim wiązać (G. Bardy, Divinisation. Chez les Peres Latin, dz. cyt., kol. 1389-1398). Bernard natomiast wyraźnie wiąże to pojęcie z ideą przebóstwienia, a w samym transformatio często akcentuje właśnie wymiar dogłębnej przemiany ludzkiej natury. Cant. 71, 5, t. 2, s. 217. Zob. też tamże, 71, 10, t. 2, s. 221.

51 „Transformamur cum conformamur. Absit autem ut in gloria maiestatis, et non magis in voluntatis modestia, Dei ab homine conformitas praesumatur". Cant. 62, 5, t. 2, s. 158.

52 Bernard z Clairvaux, Sermones de diversis, 42, w: $S B O$, ed. J. Leclercq, H.M. Rochais, Romae 1970, t. 6, 1, s. 255-261; tamże 28, 6, t. 6, 1, s. 206; Liber de gratia et libero arbitrio 28-35, w: SBO, ed. J. Leclercq, H. M. Rochais, Romae 1963, t. 3, s. 185-191; Cant. 23, 15, t. 1, s. 149; Cant. 62, 5, t. 2, s. 158; Zob. też R. Javelet, Image et resemblance..., dz. cyt., t. 1, s. 116, 188, 191, 222. Więcej na temat piszę w: Mistyczna historia człowieka według Bernarda z Clairvaux, Poznań 2011, s. 95-103, 226-229, oraz w: Idea transformacji..., dz. cyt. s. 120-122. 
sytuacji człowieka, dochodzi więc do przekształcenia tej formy, którą człowiek otrzymał w momencie stworzenia, kiedy to został uformowany przez Boga, formy określającej jego ludzką kondycję. To ona, choć nie ulega unicestwieniu ani nie przestaje udzielać człowiekowi jego tożsamości, podlega przekształceniu. W przypadku deformacji czy odnowienia przekształcenie to nie sięga jednak tak głęboko w strukturę bytu jak w przypadku transformacji, kiedy to człowiek staje się nowym stworzeniem, podobnym Bogu. Trudno o bardziej ewidentne naruszenie zasady „niezmienności istoty” w odniesieniu do bytu stworzonego.

\section{Teologia miłości}

Wywołane i usprawiedliwione przez oblubieńczą miłość zuchwałe pragnienie przekroczenia przez człowieka bariery ontycznej dzielącej go od Boga znajduje więc według Bernarda swe spełnienie w doświadczeniu zjednoczenia z Bogiem, w którym to dusza przyjmuje na siebie sposób bycia Boga.

To stawia przed nami, tak jak stawiało przed Bernardem, kolejne, jeszcze bardziej fundamentalne pytania. Kim jest Bóg, który zaprasza człowieka do takiej transgresyjnej miłości? I kim jest człowiek, który jest zdolny na taką miłość odpowiedzieć, a dzięki temu, pozostając stworzeniem, stać się Bogiem? Aby na nie odpowiedzieć, musimy wejść wraz z Bernardem na teren jego teologii i antropologii, które rozwijał on w kontekście swego mistycznego nauczania, i na gruncie których starał się wyjaśnić zagadnienie zaślubin duszy i Słowa.

Starając się określić, kim jest Bóg, Bernard często za św. Janem podkreśla, że nade wszystko „Bóg jest miłością" ${ }^{33}$. „Miłość” to imię, które najlepiej go oznacza, gdyż jest ona właśnie tym boskim atrybutem, który najlepiej oddaje Jego naturę. Aby więc móc Go zrozumieć - na tyle, na ile w ogóle jest to w doczesności możliwe - trzeba przede wszystkim zrozumieć naturę miłości, którą On jest.

Swoje fundamentalne intuicje i przemyślenia na temat natury miłości, rozwinięte później w traktacie O miłowaniu Boga, Bernard zawarł w Liście o miłości. Mówi w nim jasno, że Bóg jest miłością substancjalną czy też substancjalnie, a więc $z$ samej swej istoty, niezmiennie i doskonale, w przeciwieństwie do stwo-

53 Sententiae 3, 113, t. 6, 2, s. 199. Por. List o miłości 2, s. 57; O rozważ. 5, 28, s. 252; Serm de div. 121, t. 6, 1, s. 398; Sermones in septuagesima 2, 1, t. 4, s. 349; Cant. 18, 6, t. 1, s. 107; tamże, 83, 4, t. 2, s. 300 . 
rzeń, które są nią akcydentalnie: „miłość stwarza miłość. Miłość substancjalna stwarza miłość przypadłościową. Kiedy oznacza ona Dawcę miłości, jest nazwą substancji, kiedy zaś oznacza dar, jest nazwą przypadłości"54. Akcydentalność tą należy jednak rozumieć tak jak rozumiał ją Orygenes, od którego Bernard czerpie to rozróżnienie, czyli bardziej w duchu neoplatońskim niż arystotelesowskim: stworzenia są miłością akcydentalnie, gdyż są do niej zdolne na mocy partycypacji w jej substancjalnym Źródle. Mogą się w niej doskonalić coraz mocniej uczestnicząc w jej substancji ${ }^{55}$.

Określenie Boga jako miłości substancjalnej Bernard uzupełnia w swym $L i$ ście stwierdzeniem, że miłość jest też „prawem Pańskim”, i to jedynym Jego prawem $^{56}$. To ważne i celowe uzupełnienie. Określenie miłości jako substancji, którą Bóg „jest”, a nie np. „staje się”, mogłoby sugerować, że miłość ta ma charakter statyczny, zamknięty w sobie, niewykraczający w swej doskonałości ku innym osobom, a nawet wręcz po prostu nieosobowy. Taka sugestia bierze się stąd, że pojęcie substancji należy do kategorii metafizyki greckiej i jest obarczone blaskami i cieniami jej zasad, w tym zwłaszcza zasady „niezmienności istot”. Skoro bowiem doskonałość bytu polega na urzeczywistnieniu jego formy, wypełnieniu jej granic, to tym samym, gdy owo urzeczywistnienie się całkowicie dokona, byt z perspektywy tej doskonałości jawi się jako rzeczywistość skończona i całkowicie niezmienna, niejako zastygła ontycznie. Tym bardziej zaś jest wtedy skończona i niezmienna, im bardziej jest absolutna, niemająca w sobie żadnego braku i niepodlegająca zepsuciu. Co prawda, Arystoteles, inaczej niż Platon, twierdził, że taki doskonały Byt żyje i myśli, jednak wszystko to odbywało się w granicach Jego doskonałej Formy, nie było skierowane do nikogo ani niczego poza Nim samy w jego czystej „samotności” rozumianej jako „samowystarczalność”. Wszelka bowiem zmiana wewnętrzna czy aktywność zewnętrzna byłaby wykroczeniem poza wypełnioną już doskonale formę i oznaczała z perspektywy takiej metafizyki niedoskonałość. Dlatego Absolut filozofów starożytnych, choć był przedmiotem kontemplacji i miłości ze strony ludzi szukających doskonałości, to sam, właśnie z racji swej pełnej doskonałości, pozostawał bierny, zasklepiony w granicach bytu absolutnie spełnionego. Tym samym nie zwracał się poznaw-

\footnotetext{
$54 \quad$ List o miłości 2, s. 57.

55 Zob. H. Crouzel, Orygenes, tłum. J. Margański, Bydgoszcz 1996, s. 245. Por. O rozważ. 5, 12, s. 233.

56 List o miłości 2, s. 56
} 
czo czy miłośnie ku niczemu poza sobą, tak jak platońskie Dobro czy samo myśląca się Myśl arystotelików ${ }^{57}$.

Bernard zdawał sobie $\mathrm{z}$ tego sprawę, polemizując z formalizmem filozofów i teologów pre-scholastycznych, i bardzo dbał o to, by język teologii i filozofii był przeniknięty duchem biblijnym, widzącym doskonałość jako rzeczywistość dynamiczną, żywą, otwartą na innych, nieskończenie się udzielającą. Z tego właśnie powodu, stwierdzając, że Bóg jest miłością substancjalnie, a więc w pełni i doskonale, podkreśla też, że miłość jest Jego prawem. W ten sposób narusza granice, które to pojęcie wyznacza boskiej doskonałości, a więc i Jego miłości. A to z kolei dlatego, że przez prawo rozumie nie tyle jakiś zbiór zakazów i nakazów narzuconych Bogu i go ograniczających, ile, zgodnie z tym jak tym terminem posługiwał się w ślad za myślą biblijną monastycyzm, pewien sposób życia, regułę życia. „Prawo miłości” to w pewnym sensie Jego „zakon”, reguła, wedle której Bóg żyje, którą kieruje się w swych decyzjach, w ten sposób w nieskończoność spełniając Siebie, a zarazem potwierdzając i realizując swoją doskonałość. Z tym, że nie w samotności, lecz we wspólnocie. Reguła życia, którą kieruje się Bóg, jest wedle Bernarda - choć nie mówi tego otwarcie, lecz zdecydowanie daje się to wyczuć $\mathrm{w}$ jego sposobie opisu tego zagadnienia - podobnie jak reguły zakonne, regułą życia wspólnotowego.

„Prawo miłości”, wedle którego żyje Bóg, przejawia się bowiem przede wszystkim w tym, że choć w swej substancji jest Jeden, to zarazem jest Trójcą osób $^{58}$. Miłość przecież wymaga wspólnoty osób. Realizuje się zawsze w relacji do drugiej osoby, w pragnieniu jej, obdarowywaniu, współ-życiu z nią. Miłosne życie spełnia się więc w Bogu w postaci emanacji wewnętrznej, w której Ojciec rodzi Syna, obdarowując Go całym bogactwem swego boskiego Bytu, wszystkim, czym w swej doskonałości jest, a następnie w równie całkowitym oddaniu się Syna w swej boskości Ojcu i powiązaniu ich wzajemnych darów w Duchu Świętym. Bernard opisuje w Pieśni nad Pieśniami to wieczne, niekończące się przekazywanie sobie przez Osoby Trójcy daru Boskości, odwołując się ponownie do języka oblubieńczego - jako Boski pocałunek ust. Tylko kierując się bezwarunkową i bezgraniczna miłością, a wiec miłością podobną oblubieńczej, można bowiem całkowicie oddać siebie i całkowicie otworzyć się na drugą osobę. Ten właśnie rodzaj jednoczącej miłości w doskonały sposób dokonuje się w Bogu:

57 Arystoteles, Matafizyka, $\Lambda$, 9, 1074 b. Por. G. Reale, Historia..., dz. cyt., t. 2, s. 436-437.

58 List o miłości 2, s. 56. 
Posłuchajcie, jeśli chcecie poznać, czym jest Pocałunek ust: Ojciec i Ja jedno jesteśmy. I znowu: Ja jestem w Ojcu, a Ojciec we mnie. - oto Pocałunek ust do ust, przekraczający roszczenia jakiegokolwiek stworzenia. Oto pocałunek miłości i pokoju, miłości jednak, która przewyższa wszelką wiedzę i pokoju, który jest o tyle większy niż możemy to zrozumieć. Prawdą jest, że rzeczy, których ani oko nie widziało, ani ucho nie słyszało, rzeczy przewyższające ludzki umysł, zostały objawione Pawłowi przez Boga, przez Jego Ducha, to znaczy przez Tego, który jest Pocałunkiem Ust. To, że Syn jest w Ojcu, a Ojciec w Synu oznacza Pocałunek Ust, ale pocałunek Pocałunku odkrywamy kiedy czytamy. Zamiast ducha tego świata otrzymaliśmy Ducha, który pochodzi od Boga, aby pouczył nas i abyśmy zrozumieli dary, które nam dał ${ }^{59}$.

Prawo miłości to zatem prawo, którym żyje i dzięki któremu jednoczy się Trójca Boska. Ale jest ono też prawem, wedle którego Bóg stworzył świat, a więc dokonał emanacji zewnętrznej ${ }^{60}$. Stworzenie, które jak już widzieliśmy, partycypuje w miłości, którą jest Bóg, w różny sposób poprzez różne formy oddawana się sobie, rodzenia i jednoczenia naśladuje to Boskie prawo. Dzięki temu emanujący z Boga miłosny sposób życia „powraca do swego początku, [...] zwraca się do miejsca swego pochodzenia, [...] kieruje się ku swemu źródłu, by zawsze czerpać stąd, skąd nieustannie wypływa"61. Bernard kontynuuje tu zreinterpretowaną przez Ojców tradycje boskiego procesu wypływu i powrotu sięgającą Plotyna jedynego filozofa starożytnego, który widział w Absolucie takie Dobro, które nie tyle w swej doskonałości niewzruszenie trwa, ile udziela się emanacyjnie innym bytom $^{62}$. Opat nie skupia się jednak w swych rozważaniach na całym hierarchicznym łańcuchu stwórczej i miłosnej emanacji Boga. Interesuje go przede wszystkim człowiek, czyli jedyne ze stworzeń widzialnych, które może w pełni świadomie odpowiedzieć na miłość Boga i dzięki temu zjednoczyć się z Nim. Może zaś to uczynić, gdyż jest stworzone na Jego obraz.

59 Cant. 8, 7, t. 1, s. 40 .

${ }^{60}$ List o miłości 2, s. 57.

${ }^{61}$ Cant. 83, 4, t. 2, s. 300. Por. tamże 83, 6, t. 2, s. 302 ; tamże 7, 2, t. 1, s. 31. Por. też E. Gilson, Duch filozofi średniowiecznej, dz. cyt., s. 396-398.

62 Dla Plotyna Jednia jest nieskończona i udziela się w swej emanacji niższych hipostaz. Jednak Ona również, mimo swego emenacyjnego charakteru, nie uczestniczy aktywnie, poznawczo czy miłośnie w życiu hipostaz, a tym bardziej życiu bytów materialnych. 


\section{Antropologia miłości}

Bernard - ostatni z Ojców - uczynił zwornikiem i centralnym tematem swojej antropologii temat biblijny, wokół którego koncentrowała się też antropologia Ojców Kościoła: stworzenie człowieka na obraz i podobieństwo Boże.

Wedle opata z Clairvaux to właśnie relacja odwzorowania i podobieństwa do Boga decyduje o najgłębszej tożsamości i godności człowieka. Zasadza się ona przede wszystkim, jak oryginalnie określa to Bernard, na byciu capax Dei, czyli zdolnym Jego obecność podjąć i zawrzeć w sobie, a nawet w pewnym sensie zdolnym do bycia jak Bóg ${ }^{63}$. Dzięki temu, że jest obrazem Boga, człowiek ma bowiem zdolność otwarcia się na Niego i coraz głębszego udziału w Jego doskonałościach i Jego życiu. W tym sensie człowiek jest capax aeternitorum - zdolnym do wieczności, czy, jak moglibyśmy dziś powiedzieć, do nadprzyrodzoności ${ }^{64}$. Zdolności tej nie należy jednak rozumieć w sensie platońskim czy gnostycznym jako jakiejś „Cząstki boskości” w nas, dzięki której bylibyśmy zdolni o własnych siłach żyć jak Bóg. Na tym polegałaby raczej pokusa rajska. Dzięki darowi „obrazu i podobieństwa" człowiek, choć nie jest Bogiem, jest jednak zdolny wejść z Nim w relację duchową, a następnie w oparciu o nią poddać się procesowi wewnętrznej, sięgającej samej istoty swego bytu, przemiany na podobieństwo Jego ontycznej doskonałości, co w końcu pozwala mu zjednoczyć się z Nim i znaleźć w Nim spełnienie: „Zasługuje bowiem na dopuszczenie do wspólnoty z Duchem (societatis Spiritus) ten, kto w swej naturze jest do Niego podobny (similis in natura)" ${ }^{\prime 65}$. Można więc powiedzieć, że wykroczenie poza granice własnej natury jest wedle Bernarda zapisane w samej strukturze bytu ludzkiego, który jako imago Dei spełnić się może o tyle, o ile upodobnia się do swojego boskiego Archetypu.

Bernard wymienia wiele własności bytu ludzkiego, które składają się na doskonałość imago Dei i pozwalają mu upodabniać się do Boga. Człowiek jest podobny do Niego w swej bytowej prostocie, duchowej nieśmiertelności, w możliwości moralnego doskonalenia i osiągania prawości, w wolności swej woli, $\mathrm{w}$ umysłowych zdolnościach poznawczych. Pierwsze miejsce zajmuje jednak zdolność do miłości. Skoro bowiem miłość jest pierwszym imieniem Boga i jego najistotniejszym atrybutem, to znaczy, że człowiek jako Jego obraz został stwo-

63 Cant. 27, 10, t. 1, s. 188-189. Por. Sermones in dedication ecclesiae 2, 2, t. 5, s. 376.

64 Tamże 80, 2, t. 2, s. 278. Zob. tamże 80, 3, t. 2, s. 279.

65 Tamże 82, 7, t. 2, s. 297. 
rzony przede wszystkim ku realizacji tej właśnie zdolności. Kiedy zaś upodabnia się do Niego w miłości, może żyć tym rodzajem życia, którym w swej głębi cieszy się i kieruje Bóg. Może żyć prawem Jego natury i świadomie kierować się ku Niemu jako Źródłu.

Właściwa więc droga powrotu duszy, nie polega zaiste na niczym innym jak na jej zwróceniu się [właśc. nawróceniu] do Słowa (Pnp 7, 10), odnowieniu przez Nie i upodobnieniu do Niego. Upodobnieniu w czym? W miłości. Jest bowiem powiedziane: Bądźcie naśladowcami Boga, jako najdroższe dzieci, i postępujcie w miłości, tak jako i Chrystus was umiłowat $(\mathrm{Ef} 5,1)^{66}$.

Dlatego według Bernarda różne rodzaje miłości, które człowiek przeżywa, nawet te, które kieruje egoistycznie ku sobie, czy, już nieco mniej interesownie - ku innym ludziom, są jedynie bardziej czy mniej wykrzywionym, niedoskonałym cieniem i odblaskiem miłości, którą człowiek czerpie od Boga i dzięki której ku Niemu powraca. We wszystkich tych miłościach człowiek w istocie szuka swego miłosnego Źródła i Archetypu. Z tego też powodu nie może się w nich spełnić. Nie może bowiem znaleźć w nich tego „absolutnego” przedmiotu miłości, którego pragnie ${ }^{67}$. Wejście na drogę nawrócenia i doskonalenia duchowego - do czego skłania człowieka nie tylko płynące z wnętrza nienasycenie, ale też aktywne, miłosne wkroczenie Boga w jego życie poprzez różne teofianie - oznacza skierowanie dynamizmu miłości, którym człowiek żył dotąd i który go niepokoił, na jej właściwy przedmiot - Boga ${ }^{68}$. Zobaczenie zaś w Nim już nie tylko godnego miłości Pana czy Ojca, ale wręcz Oblubieńca pozwala na wejście na najwyższy, oblubieńczy stopień miłosnego zaangażowania. Miłość ludzka staje się wtedy w swej bezinteresowności, czystości i żarliwości podobna do absolutnej miłości, którą żyje Bóg i która jako jedyna może Go objąć. Co oznacza to upodobnienie?

Bernard chcąc to w swym komentarzu do Pieśni nad Pieśniami jak najlepiej zilustrować, znów zwraca uwagę na kwestię „pocałunku ust”, którego pragnie od Boga oblubienica, ale który też, jak widzieliśmy, wyraża prawo miłości, wedle którego żyje Trójca Osób, przekazując sobie nawzajem wszystko, czym są, i jednocząc się całkowicie w boskiej wspólnocie. Według Bernarda miłość oblubieńcza dzięki swej bezkompromisowości i transgresyjności otwiera człowieka na ten

\footnotetext{
66 Tamże, 83, 2, t. 2, s. 299.

67 O miłow. 18-20, s. 39-41.

68 Tamże, 13-15, s. 33-35.
} 
rodzaj boskiego życia. Nie chce bowiem poprzestać na mniej intymnej i mniej bliskiej relacji miłosnej właściwej dla stworzenia, a wyrażającej się w pocałunku nóg czy rąk Boga, lecz pragnie całkowicie do Niego przylgnąć. Dlaczego właśnie dusza-oblubienica $\mathrm{z}$ Pieśni nad Pieśniami wypowiada to pragnienie $\mathrm{w}$ tak dziwnej i nienaturalnej frazie: „całuj mnie pocałunkami swoich ust”, a nie po prostu "całuj mnie swoimi ustami” ${ }^{69}$. W ten sposób została według Bernarda wyrażona alegorycznie owa niezwykła tajemnica udziału stworzenia w Boskim życiu miłosnym, czyli we wzajemnym „pocałunku ust”, jaki składają sobie Boskie osoby. Człowiek, upodabniając się do Boga w swej bezwarunkowej miłości i jednocząc się z Nim, zostaje przez Niego obdarowany wszystkim, co Bóg ma. A nie ma przecież niczego lepszego od siebie, od swej boskiej natury, która w swej istocie jest wspólnotowym życiem miłosnym ${ }^{70}$. Zjednoczyć się z Bogiem to zatem nic innego jak właśnie mieć udział w Jego wewnętrznym doskonałym życiu, które wyraża się w niekończącym się „pocałunku ust” składanym sobie przez Osoby boskie dzielące się całym bogactwem swego bytu. I choć człowiek jako stworzenie nie może żyć tym życiem ze swojej natury - nie może więc otrzymać „pocałunku ust”, wyrażającego substancjalność i całkowitą jedność miłosnej relacji z Bogiem, i będącego przywilejem wcielonego Słowa ${ }^{71}$ - to jako capax Dei może mieć w nim swój udział, może zostać ku temu życiu w doświadczeniu mistycznym, tak jak św. Paweł, podniesiony, a w stanie eschatologicznym - włączony w nie. Dlatego właśnie otrzymuje nie tyle „pocałunek ust”, ile „pocałunek pocałunku”:

Musimy jednak uczynić jasne rozróżnienie pomiędzy tymi dwoma pocałunkami. Ten, który otrzymał Pełnię, otrzymuje Pocałunek Ust. Ten, który jednak otrzymał z Pełni, dostał pocałunek Pocałunku. Paweł, z pewnością był wielkim człowiekiem, bez względu jednak na to, jak wysoko by mierzył, składając ofiarę swoich warg, nawet gdyby miał się unieść do trzeciego nieba, nadal, z konieczności, znajdowałby się daleko od warg Najwyższego. Musiał się zadowolić tym, co pozostaje w granicach jego możliwości. A ponieważ nie może on sam z siebie dosięgnąć tego chwalebnego Oblicza, niech w pokorze prosi, by Ono skłoniło się ku niemu i by pocałunek został mu przekazany z wysoka. Dla Chrystusa zatem - pocałunek oznaczał całkowitość, dla Pawła - uczestniczenie. Chrystus radował się Pocałunkiem Ust, Paweł jedynie tym,

Zob. Cant. 4, 1-2, t. 1, s. 18-19. Por. Cant. 8, 1-2, t. 1, s. 36-37.

O miłow. 22, s. 42.

Cant. 2, 2-3, t. 1, s. 9-10. 
że był obdarowany Pocałunkiem. Szczęśliwy jest jednak pocałunek uczestniczenia, który pozwala nam nie tylko poznać Boga, ale także kochać Ojca, który nigdy w pełni nie jest poznany dopóki nie jest doskonale kochany ${ }^{72}$.

Kochać zaś doskonale to kochać tak, jak tylko On ze swej natury potrafi. Człowiek włączony w życie miłosne, które stanowi naturę Boga, ostatecznie dostosowuje formę swojego bytu do Jego Bytu, czyli do Jego miłości:

Tego rodzaju uzgodnienie (conformitas) zaślubia [jego] duszę ze Słowem. O ile bowiem jest podobna do Niego z natury, o tyle ukazuje się nam jeszcze bardziej podobną do Niego w działaniu swej woli, kochając tak, jak jest kochana ${ }^{73}$.

A jak jest kochana? Czym ta miłość się charakteryzuje? Ma wszystkie cechy doskonałej miłości oblubieńczej, ale oprócz nich jeszcze jedną, być może najważniejszą, będącą fundamentem wszystkich innych: jest bezmierna. Jaką bowiem miarę można postawić naturze i życiu Tego, który nie ma w sensie ścisłym żadnej formy ani żadnej miary, która by Go ograniczała. To, że taki Jest i że tak kocha, ukazywał stopniowo w historii zbawienia, by ostatecznie dowieść tego na Krzyżu. „Rozważ więc nasamprzód - zwraca się Bernard do czytelnika jego traktatu o miłości - w jaki sposób, w jakiej mierze, albo raczej bez miary, Bóg zasługuje na miłość naszych serc. Ten Bóg, który - by przypomnieć jeszcze - umiłował nas pierwszy. Umiłował bezgranicznie, On, Nieskończony - nas, nędznych i niegodnych" ". Człowiek uwiedziony taką miłością, dostosowując do niej (conformatio) i przemieniając na Jej podobieństwo (transformatio) otwiera się zatem na życie bez żadnej miary. I tylko w takim, podobnym mu sposobie absolutnego miłosnego życia, może w pełni cieszyć się owym absolutnym Dobrem, które Bóg mu ofiarowuje:

Dlatego też powiedziałem: miarą miłości Boga jest miłość bez miary. Bowiem miłość ta obejmuje niezmierzoność i nieskończoność, tak jak Bóg jest niezmierzony i nieskończony ${ }^{75}$.

\footnotetext{
Tamże, 8, 8-9, t. 1, s. 41-42.

Tamże, 83, 3, t. 2, s. 299.

O miłow. 1, s. 22. Por tamże, 22, s. 43; Cant. 83, 4, t. 2, s. 301.

Tamże, 1, s. 22.
} 


\section{Transgresja i kenoza}

Zuchwałość oblubienicy może więc jawić się jako niewłaściwa i nieodpowiedzialna jej towarzyszkom nieznającym jej prawdziwej natury, ale już nie samemu Oblubieńcowi. Skoro bowiem Bóg stwarzając człowieka na swój obraz, powołał go i wezwał do równie „bezmiernej” miłości, jak ta, wedle której sam żyje, to można powiedzieć, że On sam jest „winny” owej oblubieńczo mistycznej zuchwałości popychającej człowieka do przekraczania miary stworzenia, czyli do wykraczania poza granice własnej natury.

Co więcej, sam jest dla człowieka w tym „występku” wzorem i przykładem. Bernard, patrząc na historię zbawienia jako teofanię miłości, widział, że Bóg nie tylko jako pierwszy okazał człowiekowi bezmierną miłość, ale też jako pierwszy w jej imię dokonał analogicznej, zuchwałej miłosnej transgresji. Aby bowiem przekazać człowiekowi, który przecież „nie może sam z siebie dosięgnąć jego chwalebnego Oblicza”, pocałunek ust, aby włączyć go w to boskie życie, do której go powołał jako capax Dei, musiał „skłonić się ku niemu z wysoka” we Wcieleniu $^{76}$. To zaś oznaczało dla Niego kenozę, czyli ten rodzaj zniżenia się do rangi stworzeń, który jawił się „głupotą dla Greków i zgorszeniem dla Żydów” (por. 1 Kor 1, 22-23). Dla Greków było to absurdalne metafizycznie, gdyż jak widzieliśmy, Absolut był wedle nich w swej doskonałości nieporuszony, stąd mógł być jedynie przedmiotem kontemplacji czy miejscem unicestwiającego roztopienia się, ale na pewno nie kimś, kto interesuje się człowiekiem, kocha go, a tym bardziej zstępuje ku jego niedoskonałości. Z kolei dla Żydów, którzy inaczej niż Grecy poznali Boga jako miłującego i interesującego się człowiekiem, było to nie do przyjęcia z perspektywy religijnej, istniała bowiem wedle nich wyraźna granica tego Boskiego zwrócenia się ku swemu stworzeniu: nie mógł On zrezygnować ze swojego boskiego Majestatu, gdyż byłaby to oznaka jego słabości, a nie mocy. Bernard, odwołując się do takiego grecko-judaistycznego wyobrażenia doskonałości Boga, przyjmując je niejako za swoje, ukazuje kenotyczną prawdę Wcielenia w przejmującym fragmencie ze swego komentarza do Pieśni nad Pieśniami:

W jaki sposób ja, proch i popiół, mogę sądzić, że Bóg interesuje się mną? Zajmuje się całkowicie kochaniem swojego Ojca, nie potrzebuje mnie ani tego, co posiadam. W jaki sposób zatem, znajdę zapewnienie, że jeśli On jest moim

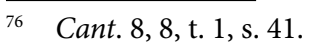


pośrednikiem, nigdy mnie nie zawiedzie? Jeśli to rzeczywiście jest prawda, jak mówili prorocy, że Bóg postanowił okazać miłosierdzie, ukazać się w łaskawszym świetle, niech zawrze przymierze pokoju, nieskończone przymierze ze mną, przez pocałunek swoich ust. Jeśli nie odwoła danego słowa, niech się ogołoci i niech się upokorzy. Niech pochyli się nade mną i pocałuje mnie pocałunkiem swoich ust. Jeśli pośrednik ma zostać przyjęty przez obie strony, tak samo godny zaufania w oczach obydwu stron, niech zatem ten, który jest Synem Bożym, stanie się człowiekiem, niech się stanie synem człowieczym i napełni mnie pewnością, przez pocałunek swoich ust. Kiedy rozpoznam, że On jest prawdziwie mój, wtedy będę czuł się pewien, przyjmując Syna Bożego, jako pośrednika. Nawet cień nieufności nie może wówczas istnieć, bo przecież jest On moim bratem i moim własnym ciałem. Niemożliwe jest, abym został odrzucony przez Niego - kość z moich kości, ciało z mego ciała. Zrozumieliśmy teraz, w jaki sposób niezadowolenie naszych przodków ukazywało potrzebę tego najświętszego pocałunku, to znaczy - tajemnicy Wcielonego Słowa"77.

Powyższe słowa Bernarda są dość niezwykle, gdyż znów łatwo mogą być odczytane jako „nie na miejscu”. Bernard bowiem nie tylko świadczy w nich o fakcie ogołocenia się Boga, który jest tu określony „pocałunkiem Boga”, czyli aktem jego niezmierzonej miłości wobec stworzenia, ale wręcz niejako się tego od Boga domaga, tak jakby chciał powiedzieć: „trudno byłoby mi uwierzyć, podobnie jak Grekom i Żydom, że nieskończony w swym majestacie Absolut kocha mnie, takie nędzne stworzenie, gdyby nie dokonał rzeczy tak filozoficznie niemożliwej i religijnie skandalicznej jak zniżenie się do mojej kondycji, czyli w jakimś sensie nie zrezygnował dla mnie ze swojej niewzruszonej absolutności”. Bernard jednak mówiąc w ten sposób o Wcieleniu nie tyle odchodzi od przesłania chrześcijańskiego, ile przeciwnie - dotyka samej jego istoty, która nie tylko wymyka się rozumowi jako tajemnica, ale też niejednokrotnie przekracza granicę tego, co wydaje się nam rozsądne i właściwe. Przecież od samego początku przesłania chrześcijańskiego czyny, których Bóg dokonuje w imię miłości do człowieka, zwłaszcza Wcielenie i Ukrzyżowanie, są ukazywane jako „skandaliczne”, „szalone”, nie do przyjęcia z perspektywy mentalności człowieka i obrazów Boga, jakie stworzył. A dzieje się tak przede wszystkim właśnie z powodu ich transgresyjności. Dla Boga bowiem zniżyć się do kondycji ludzkiej i dokonać ogołocenia, to

Tamże, 2, 6, t. 1, s. 11. 
w istocie wykroczyć poza niewzruszoność własnej natury, a tym samym dokonać transgresji zuchwałej wobec ludzkiego rozumienia doskonałości i boskości. Jak to pogodzić z monoteistyczną transcendencją Jedynego wobec swego stworzenia? Jak pogodzić z odziedziczonym po Grekach rozumieniem Absolutu, dla którego każda zmiana, każde ogołocenia z jakiś „atrybutów” oznacza unicestwienie, a tym samym jest niedorzeczne? Teologia chrześcijańska operując w wielu kwestiach z powodzeniem tym „teistycznym” system pojęciowym, zarazem od wieków aż do dziś zmaga się z pogodzeniem tych pojęć z prawdą Wcielenia i Krzyża. Nie wiedząc zaś niejednokrotnie możliwości osiągniecia w tym względzie zadowalającej ścisłości, ulega pokusie oswojenia i rozbrojenia „skandalu” kenozy poprzez sprowadzenie go do "tajemnicy” i skrycie za systemem bezpiecznych pojęć rozgraniczających to, co „ludzkie”, i to, co „boskie”78.

Bernard mimo całej swojej dbałości o nienaruszanie w niczym ortodoksji nie unikał ukazywania „skandalicznego” metafizycznie i religijnie wymiaru prawdy chrześcijańskiej ${ }^{79}$. Nie unikał tego, jak widzieliśmy, gdy pisał o miłosnym, oblubieńczym powołaniu człowieka. Ale nie unikał też, gdy pisał o miłosnym, kenotycznym zaangażowaniu w ludzką historię Boga. Można zaś odnieść wrażenie, że to właśnie świadomość „bezmierności” miłości Boga pozwalała mu na „zuchwałe” przekraczania miary na gruncie swej mistyki. Należy bowiem przyznać, że w opacie z Clairvaux nie było tej dozy śmiałości i prowokacyjności, graniczącej z nieostrożnością, która będzie charakteryzować Eckharta i innych mistyków nadreńskich. Zazwyczaj, gdy przedstawiał swą mistyczną doktrynę, dbał, by w niczym nie naruszyć ortodoksji i by nie zgorszyć mogących go źle zrozumieć mnichów. Wiedział, że łatwo mogą pomylić śmiałość z perwersją, a bez-

78 Np. widząc stan eschatologiczny w owej bezpiecznej „odrębności” tego, co ludzkie, i tego, co boskie, jako wizję, która choć odbywa się twarzą w twarz, pozwala zachować dystans ontyczny. W scholastyce znajdzie to wyraz w koncepcji potentia oboedientialis, w której nadprzyrodzoność rozumiana jest jako specjalna „nadbudowa” dodana do w pełni integralnej i nienaruszalnej „bazy”, jaką pozostaje nasza natura. Zob. E.L. Mascall, Otwartość bytu, tłum. S. Zalewski, Warszawa 1988, s. 174-192, 277-290.

79 Opat z Clairvaux jest jednak jak najdalszy od kwietyzmu, jeżeli chodzi o relację bliskości z Bogiem. Akt miłości nie może zaistnieć ani się doskonalić bez aktu poznawczego: nie można bowiem „miłować tego, czego się nie zna” (Cant. 37, 1, t. 2, s. 9), a „kogo się mniej poznaje, mniej się miłuje" ( $O$ miłow. 14, s. 34). Rozum i wola, poznanie i miłość to wedle niego dwa skrzydła niezbędne do wznoszenia się ku Bogu. I choć żar miłości ma w tym wznoszeniu ostatnie słowo, pozwala bowiem podążać dalej, gdy rozum już oślepnie, to jednak, na ile to tylko możliwe, rozum towarzyszy miłości. 
kompromisowość z powodowanym pychą uporem ${ }^{80}$. Sam też wciąż czuł „bojaźń i drżenie" przed takim pseudo mistycznym wzlotem ${ }^{81}$. Dlatego wielokrotnie w opisach mistycznego zjednoczenia czynił krok do tyłu, zaznaczał odrębność bytową Boga i człowieka, podkreślał różnicę miedzy duszą a Słowem, zginał się w pokorze przez Wielkością Boga. Widzieliśmy to wyraźnie w cytowanym fragmencie o „pocałunku ust”, w którym opat podkreślał, że Paweł otrzymuje nie „Pełnię” boskości, a jedynie „z Pełni” boskości, gdyż takie są „granice jego możliwości”. Mówi jednak to wszystko, by zaraz potem w dialektycznym ruchu uczynić krok albo nawet dwa kroki do przodu i podkreślić, że ów pocałunek pozwala jednak duszy na „uczestnictwo" w boskim życiu, w doskonałym poznaniu i kochaniu, i że nie powinniśmy się zatrzymywać w pragnieniu coraz głębszego w nim uczestnictwa, w proszeniu o „więcej”, gdyż miłość usuwa wszelki lęk przed „wielkościami”.

Popychała go zaś do tego nie tylko głębia doświadczenia duchowego, odkrycie natury miłości oblubieńczej i jej zuchwałości, lecz także świadomość, że w ten sposób człowiek stworzony na obraz Boga naśladuje Jego czyny. Tak jak Oblubienicę do prośby o większą bliskość Oblubieńca ośmielał oprócz wewnętrznego żaru fakt, że boski Oblubieniec ją do takiego zachowania prowokuje, uwodząc ją i sam dając dowody miłosnego „upojenia”, tak Bernarda jako teologa do głoszenia prawdy o transgresywnym wymiarze miłości oblubieńczej ośmielała świadomość ewangelicznej prawdy, że Bóg jako pierwszy takiej miłosnej transgresji dokonał ogołociwszy się dla człowieka ze swego Majestatu - najpierw we Wcieleniu, a następnie, $\mathrm{w}$ jeszcze większym stopniu, $\mathrm{w}$ doświadczeniu poniżenia i śmierci na Krzyżu. Prawda ta była dla niego w pewnym sensie ostatecznym objawieniem i potwierdzeniem powołania człowieka do udziału w bezmiernej, zuchwałej miłości, która wykracza poza granice tego, co niemożliwe. Przynajmniej z perspektywy naszych norm doskonałości.

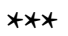

Wydobywając i akcentując w swym komentarzu do Pieśni nad Pieśniami zuchwały i bezkompromisowy charakter miłości oblubieńczej, Bernard odsłania

\footnotetext{
80 Zob. Cant. 34, 1, t. 1, s. 246.

81 Zob. tamże, 3, 5, t. 1, s. 17.
} 
tė̇ przed nami jej wymiar transgresywny. To w jej imię bowiem oblubienica z Pieśni nad Pieśniami przekracza normy społeczne odgradzające ją od Oblubieńca, dusza w swym dążeniu do jedności z Bogiem przekracza granice swej stworzonej natury, a mistyk podważa zasady klasycznej metafizyki. Samo pojęcie transgresji wymaga jednak na koniec jeszcze pewnego dopowiedzenia. Współcześnie jest ono bowiem używanie głównie na oznaczenie przekraczania norm społecznych i moralnych, jakie dominowały dotąd w świecie Zachodnim, a ustanowione zostały przez kulturę chrześcijańską. Z tego też powodu „transgresja” ma na gruncie współczesnej teologii i filozofii chrześcijańskiej wydźwięk negatywny, utożsamiana jest zazwyczaj z deprawacją czy grzechem, oraz przeciwstawiana „transcendencji”. Wydaje się jednak, że takie zawężanie tego pojęcia ani nie jest konieczne, ani nie służy samej myśli chrześcijańskiej. W istocie bowiem w opartej na kategorii obrazu i podobieństwa antropologii chrześcijańskiej zawsze podkreślano, że człowiek jest powołany do przekraczania swej stworzonej kondycji. To przekraczanie można określić jako transcendowanie siebie, ale można też - jako transgresję, zwłaszcza gdy jest związane z wykraczaniem poza pewne normy, czy to społeczne, czy duchowe, czy teologiczne, a z tym właśnie mamy do czynienia tak w przypadku opisu miłości oblubieńczej przez Bernarda, jak też we wschodniej teologii przebóstwienia (oraz wielu rozwijanych w następnych wiekach zachodnich doktrynach mistycznych). Nie znaczy to oczywiście, że antropologia Ojców czy mistyka Bernarda sankcjonują wszelki rodzaj transgresji norm obyczajowych czy dogmatycznych. „Oblubienica Pana - jak zaznacza Bernard - nie powinna być głupia" ${ }^{\prime 2}$. Dynamizm transformacji i transgresji wpisany w kategorię imago et similitudo Dei może być realizowany tak, że człowiek podejmując jego ukierunkowanie, przekracza swoją naturę, by przywdziać Boską doskonałość, lub też tak, że wypaczając go, przekracza to, co ludzkie i Boskie, by upodobnić się do zwierząt i przywdziać maskę „bestii”83.

Innymi słowy, metafizyczna otwartość bytu ludzkiego stworzonego jako capax Dei niesie w sobie zarazem wielkie powołanie jak i wielkie ryzyko. Podobnie jak ściśle z nim związana wolność. W tym kluczu należy też patrzeć na kwestie transgresji norm. Antropologia Bernarda nie tyle jej zabrania, ile ukazuje jej właściwe w swym przekonaniu ukierunkowanie i prawdziwy sens.

82 Tamże, 69, 2, t, 2, s. 203.

83 Tamże, 82, 2, t. 2, s. 293. Por. Grzegorz z Nyssy, O stworzeniu człowieka 17-18, tłum. M. Przyszychowska, Kraków 2006, s. 97-103. 


\section{Bibliografia}

Arystoteles, Fizyka, tłum. K. Leśniak, w: Arystoteles, Dzieła wszystkie, Warszawa 1990, t. 2.

Arystoteles, Metafizyka, tłum. K. Leśniak, w: Arystoteles, Dzieła wszystkie, Warszawa 1990, t. 3.

Atanazy z Aleksandrii, O wcieleniu Słowa, tłum. M. Wojciechowski, Warszawa 1998.

Bardy G., Divinisation. Chez les Pères Latin, w: Dictionnaire de spiritualité ascétique et mystique, t. 3, kol. 1389-1398.

Bernard z Clairvaux, Kazania o Najświętszej Maryi Pannie, tłum. I. Bobicz, Warszawa 2000.

Bernard z Clairvaux, O miłowaniu Boga i inne traktaty, tłum. S. Kiełtyka, Poznań 2000

Bernard z Clairvaux, Sancti Bernardi Opera, 8 t., ed. J. Leclercq, H.M. Rochais i C.H. Talbot, Editiones Cistercienses, Romae 1957-1977.

Coune M., Grace de la Transfiguration d'apres les Peres d'Occident, Bellefontaine 1990.

Crouzel H., Orygenes, tłum. J. Margański, Bydgoszcz 1996.

Déchanet J.M., Amor ipse intellectus est, „Revue du moyen âge latin” 1945, nr 1, s. 349-374.

Delfgaauw P.P., La nature et les degrés de l'amour selon saint Bernardi, w: Saint Bernard théologien. Actes du congrès de Dijon. 15-19 septembre 1953, „Analecta Sacri Ordinis Cisterciensis” 1953, nr 9, s. 234-252.

Fracheboud M.A., Divinisation. Auteurs monastique du 12e siècle, w: Dictionnaire de spiritualité ascétique et mystique, t. 3, kol. 1399-1431.

Gilson E., Duch filozofii średniowiecznej, tłum. J. Rybałt, Warszawa 1958.

Gilson E., La théologie mystique de saint Bernard, Paris 1934.

Grzegorz z Nyssy, O stworzeniu człowieka, tłum. M. Przyszychowska, Kraków 2006.

Hadot P., Teologia, egzegeza, objawienie i Pismo w filozofii greckiej, w: Platon, Eutyfron, Warszawa 2015, s. 284-315.

Halflants A.C., La doctrine spirituelle de S. Bernard, "Collectanea Cisterciensia” 1975, nr 37, cz. I, s. 227-249; 1976, nr 38, cz. II, s. 40-59; cz. III, s. 134-146. 
Jaeger W., Paideia, tłum. M. Plezia i H. Bednarek, Warszawa 2001.

Javelet R., Image et ressemblance au douzième siècle. De saint Anselme à Alain de Lille, Paris 1967.

Kirk G.S., Raven J.E., Schofield M., Filozofia przedsokratejska, tłum. J. Lang, Warszawa 1999.

Leclercq J., La spiritualité du moyen âge. De saint Grégoire à saint Bernard, w: Histoire de la spiritualité chrétienne, t. 2, Paris 1961, s. 11-272.

Leclercq J., S. Bernard et la théologie monastique du XII e siècle, w: Saint Bernard théologien. Actes du congrès de Dijon. 15-19 septembre 1953, „Analecta Sacri Ordinis Cisterciensis" 1953, nr 9, s. 7-23.

Louth A. Początki mistyki chrześcijańskiej, tłum. H. Bednarek, Kraków 1997.

Mascall E.L., Otwartość bytu, tłum. S. Zalewski, Warszawa 1988.

Matter E. Ann., The Voice of My Beloved. The Song of Songs in Western Medieval Christianity, University of Pennsylvania 1992.

Orygenes, Komentarz do Pieśni nad pieśniami, Prol. 4, tłum. S. Kalinkowski, Kraków 1994.

Places E. des, Divinisation. Pensée religieuse des Grecs, w: Dictionnaire de spiritualité ascétique et mystique, t. 3, kol. 1370-1375;

Reale G., Historia filozofii starożytnej, tłum. E.I. Zieliński, Lublin 1999.

Robertson D., Lectio Divina. The Medieval Experience of Reading, Cistercian Publications 2011.

Standaert M., La doctrine de l'image chez Saint Bernard, „Ephemerides Theologicae Lovaniensis" 1947, nr 23, s. 70-129.

Ślaski S., Zachowania transgresyjne - próba psychologicznego pomiaru, „Przegląd Psychologiczny" 2010, t. 53, nr 4, s. 401-416.

Taubes J., Hegel, „Kronos” 2014, nr 4, s. 133-137.

Tichy R., Idea transformacji natury ludzkiej w myśli patrystycznej i średniowiecznej: w: Fenomen tego, co nadchodzi, Poznań 2020, s, 103-125.

Tichy R., Mistyczna historia człowieka według Bernarda z Clairvaux, Poznań 2011. 


\section{Streszczenie}

Artykuł przedstawia cechy charakterystyczne mistyki oblubieńczej Bernarda z Clairvaux. Zwraca zaś szczególną uwagę na mało dotąd eksponowaną przez badaczy jej cechę, jaką jest jej zuchwałość i w konsekwencji transgresyjność. To w jej imię oblubienica z Pieśni nad Pieśniami przekracza normy społeczne odgradzające ją od Oblubieńca, dusza w swym dążeniu do jedności z Bogiem przekracza granice swej stworzonej natury, a mistyk podważa zasady klasycznej metafizyki.

Słowa kluczowe: mistyka oblubieńcza, przebóstwienie, transgresja

\section{Summary}

\section{Transgression in the Spousal Love of Bernard of Clairvaux}

The essay presents a characteristic of Bernard of Clairvaux's nuptial mysticism. It addresses especially its audacity and resulting transgressiveness, a feature rarely exposed by scholars. It is for the sake of her Bridegroom that he bride in the Song of Songs transgresses social norms that separate her from the Bridegroom, the soul in its pursuit of unity with God transcends the boundaries of her created nature, and the mystic defies the principles of classical metaphysics.

Key words: nuptial mysticism, deification, transgression 